University of Louisville

ThinkIR: The University of Louisville's Institutional Repository

Electronic Theses and Dissertations

$5-2012$

\title{
Art as a media for social commentary : a case study of Igbo bongo musicians, south-eastern Nigeria.
}

Ruth Stellamaris Opara 1980-

University of Louisville

Follow this and additional works at: https://ir.library.louisville.edu/etd

\section{Recommended Citation}

Opara, Ruth Stellamaris 1980-, "Art as a media for social commentary : a case study of Igbo bongo musicians, south-eastern Nigeria." (2012). Electronic Theses and Dissertations. Paper 1081.

https://doi.org/10.18297/etd/1081

This Master's Thesis is brought to you for free and open access by ThinkIR: The University of Louisville's Institutional Repository. It has been accepted for inclusion in Electronic Theses and Dissertations by an authorized administrator of ThinkIR: The University of Louisville's Institutional Repository. This title appears here courtesy of the author, who has retained all other copyrights. For more information, please contact thinkir@louisville.edu. 


\title{
ART AS A MEDIA FOR SOCIAL COMMENTARY: A CASE STUDY OF IGBO BONGO MUSICIANS, SOUTH-EASTERN NIGERIA
}

\author{
By \\ Ruth Stellamaris Opara \\ B. A., University of Nigeria

\begin{abstract}
A Thesis
Submitted to the Faculty of the

College of Arts and Sciences of the University of Louisville in Partial Fulfillment of the Requirements

for the Degree of
\end{abstract}

\author{
Master of Arts \\ Department of Pan African Studies \\ University of Louisville \\ Louisville, Kentucky
}

May 2012 


\title{
ART AS A MEDIA FOR SOCIAL COMMENTARY: A CASE STUDY OF IGBO BONGO MUSICIANS, SOUTH-EASTERN NIGERIA
}

\author{
By \\ Ruth Stellamaris Opara \\ B.A., University of Nigeria
}

A Thesis Approved on

April 25, 2012

by the following Thesis Committee:

Dr. Theresa Rajack-Talley

Thesis Director

Dr. J. Blaine Hudson

Dr. Nefertiti Burton 


\section{DEDICATION}

I dedicate my thesis to my lovely parents

Chief \& Lolo Paul Johnson Opara

and sibling

whose prayers saw me through. 


\section{ACKNOWLEDGMENTS}

I would like to thank my committee members Dr. Rajack Tally, Dr. J Blaine Hudson and Dr. Nefertiti Burton for their assistance. I would also want to thank Rev. Fr. Dr Chikwendu P. Anyanwu for being there for me always. A special thank you to Dr. Alicestyne Turley for being a sister in the Diaspora. 


\begin{abstract}
ART AS A MEDIA FOR SOCIAL COMMENTARY: A CASE STUDY OF IGBO BONGO MUSICIANS, SOUTH-EASTERN NIGERIA

Ruth Stellamaris Opara
\end{abstract}

April 25, 2012

This study investigates the use of bongo music as a medium for social commentary in society. African traditional musicians, without formal education have been able to address socio-political and moral issues. The methodology includes the use of autobiographic stories and lyrical analysis. The lyrics are drawn from the musical CDs of two musicians who are of different generations. Reviews of literatures are also used to discuss the historical background of Nigeria and the Igbo people, the function of music in the life of an African culture including music, and the impact of colonization in African music. The analysis explores the musicians' ability to resist cultural hegemony through musical instruments, language and lyrics. The lyrics specifically address issues of decolonization, unity, family relations and social justice. By addressing socio-political and moral issues, these bongo musicians have been able to provide philosophical insight into the African way of life. 


\section{TABLE OF CONTENTS}

PAGE

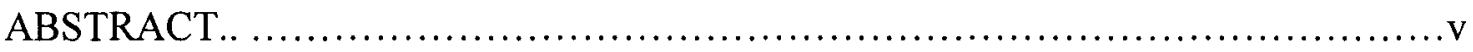

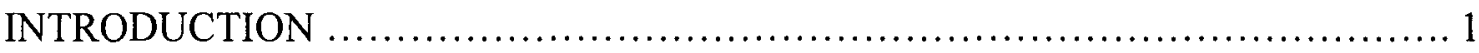

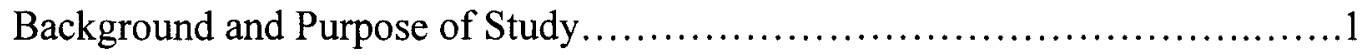

Statement of Problem/Limitation of Study .................................5

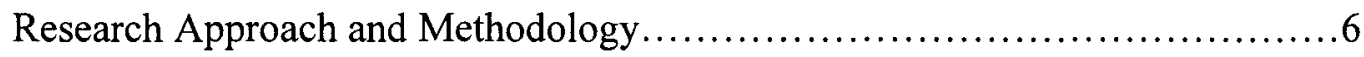

Structure of the Thesis.................................................. 7

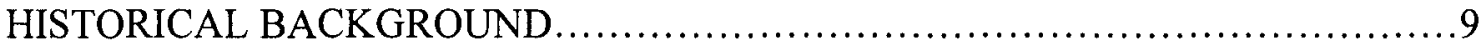

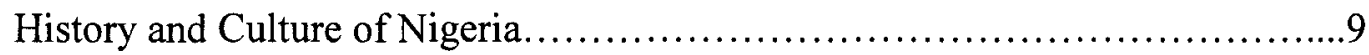

History and Culture of Igbo people........................................14

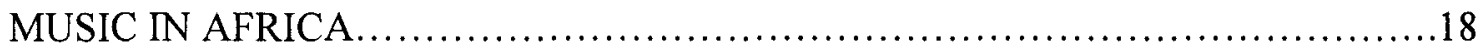

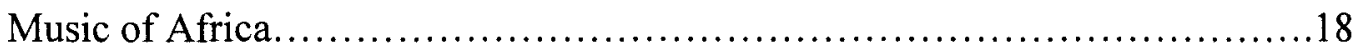

Characteristics of African Music..............................................19

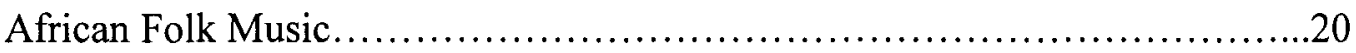

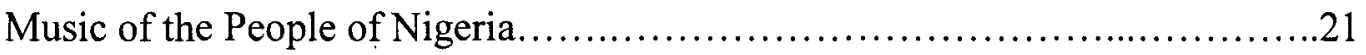

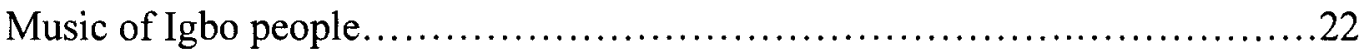

The Communal Nature and Functions of Music in Igbo Society.................23

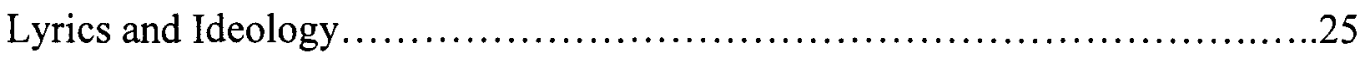

History and Nature of Bongo Music .......................................26

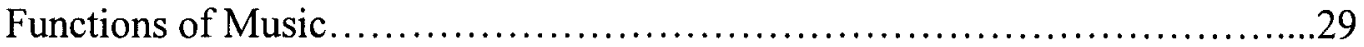


COLONIZATION AND CULTURAL HEGEMONY IN AFRICA.......................44

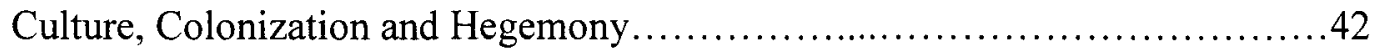

Impact of Colonization in African Music and Culture........................46

Pre colonial African Music and Culture......................................49

Cross Currents: Music of Africa and the Africa Diaspora........................50

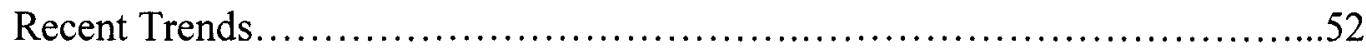

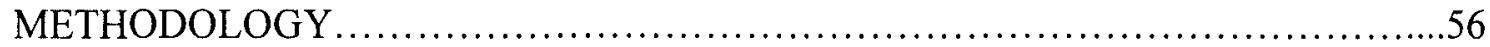

Research Purpose and Specific Objectives...................................56

Methodological approach..............................................56

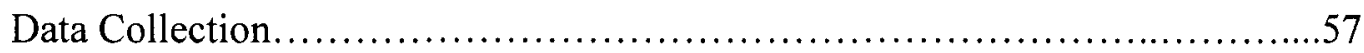

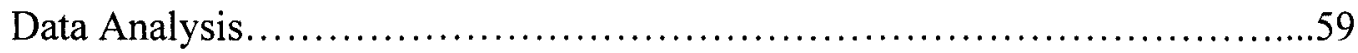

Limitations, Validity, Reliability and Generalization........................61

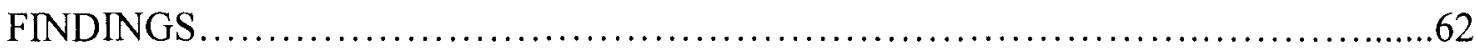

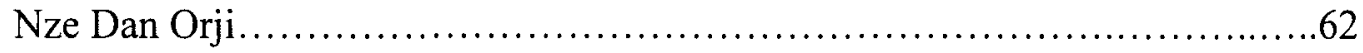

Negotiating Cultural Hegemony...........................................68

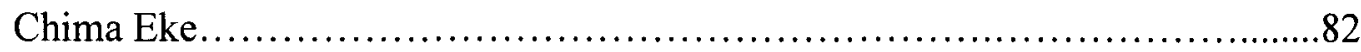

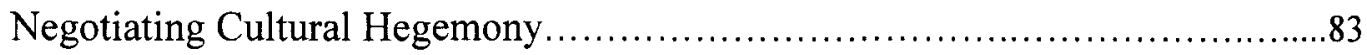

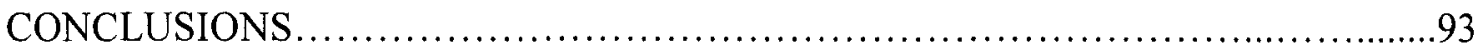

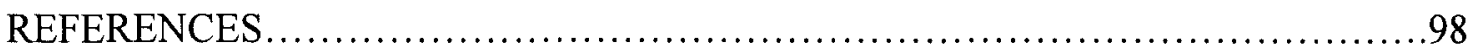

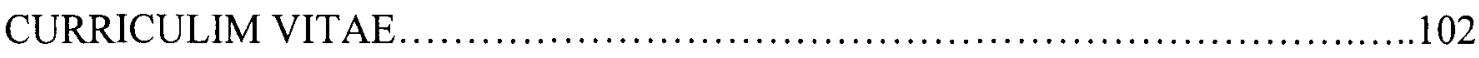




\section{CHAPTER ONE}

\section{INTRODUCTION}

\section{Background and Purpose of Study}

Music in many cultures has always been a mode of communication; it has been a repertoire of knowledge and of intellectual and life expressions. Music is the sound image of a people, or their identity. Indeed, African music in general, and Igbo music in particular, is the image of the people. ${ }^{1}$ The assumption is often made that philosophies are the preserve of the West and East, and that Africa has no philosophical leanings. These assumptions can easily be refuted by merely examining some of the themes and lyrics of the songs that Africans sing and the messages they communicate. ${ }^{2}$ This idea is at the center of the present study. Igbo music could be rightly referred to as an art and a medium that pleasantly transmits the people's ways of life. As such, the music time functions as a conservatory for Igbo history and ideologies.

This study investigates the form and content of African music as a way of resisting cultural hegemony and communicating African philosophical reflections of life. Additionally, this research examines bongo music as a medium for social commentary historically. It explores how bongo music is still practised in contemporary Igbo society of south-eastern Nigeria. Inherent in the analysis is the extent to which bongo musicians (similar to the role played by the emergent Western educated African elite of the colonial

\footnotetext{
${ }^{1}$ Ewen, Africa O-Ye! A Celebration of African Music, 6.
}

${ }^{2}$ Oti, Highlife Music in West Africa, 45. 
and postcolonial orders) are able to function traditionally as social commentators and leaders of opinions in society. This study investigates how these artists use their music as a forum through which they air their views on politics and culture; how they serve as social critics, and offer critical insights into socio-cultural currents, while entertaining their audiences. It inquires how African musicians who are believed to be custodians of elements of Igbo life and customs engage in poetries, folklores/folktales, and proverbs that, altogether, help preserve the history, culture, value systems, and traditions of the people; and how they transmit these traditions from one generation to the next.

The Igbo people are believed to be naturally gifted in art, especially music that has rich and diverse genres. There are various tribes, groups, and local communities according to their size and degree of social coherence. The Igbo are considered one ethnic group in which a number of related dialects are spoken. The Igbo people occupy a tract of territory and share a common social structure and culture. There are no formal political conformities or differences, but the borders are marked by dialectical and cultural differences among the various main groupings. ${ }^{3}$ Communal life, within limits, is a factor in the life of the people; despite the fact that the Igbo speak the same language, and, in times of peace intermarry with one another, the nearest neighbors and the outcasts $^{4}$ may still be regarded as strangers. ${ }^{5}$

Igbo music is the music of the Igbo people, and it is an embodiment of their social and philosophical beliefs. The music and dance accompany each other to mark all

\footnotetext{
${ }^{3}$ Forde \&Jones, The Ibo and Ibibio-Speaking Peoples of South-Eastern Nigeria, 9. ${ }^{4}$ Outcasts are regarded as 'Osu' in Igbo culture. It is believed that they are sacrificed to the gods and all their generations are regarded as Osu.

${ }^{5}$ Basden, Among the Ibos of Nigeria, 121.
} 
aspects of human development and existence, from birth to death. While there are diverse genres of music among the Igbo, such as Atilogwu, Igba ndi Eze, Nkwa umu agboho and others, this study explores the genre that embodies social commentaries and how they are used to resist cultural hegemony. Moreover, this research specifically examines the lyrics that deal with decolonization, unity, social justice and family relations.

Bongo music is a genre of highlife music of West Africa identified by its unique rhythm. Bongo music is meant to teach, entertain, and to preserve the history and culture of the people. Among the Igbo, this brand of music evolved from the cultural music of different communities in Owerri South-eastern Nigeria, through the introduction of the 'bongo' drum as the lead. ${ }^{6}$ As a sub-genre of highlife music, which later incorporated Western musical instruments, bongo music is characterized by the dominance of the drums during performance.

However, beyond instrumentation, the bongo artists have a rich well of knowledge to offer society. Using Igbo language as their primary means of communication, the musicians continued with their poetic and ideological trends in traditional music. ${ }^{7}$ These songs have become banks for Igbo idioms, proverbs, and parables. In the $1970 \mathrm{~s}$, bongo highlife music basically became the most effective performing art medium for the transmission of Igbo socio-moral instructions and philosophy. The musicians not only fed off the time-honored Igbo idioms and proverbs, they gave them new life and, sometimes, they brought new sayings into being. For example, every song by the Oriental Brothers musical band, which dominated highlife music in the 1970s and 1980s in Owerri, was considered a hit, and their popularity as

\footnotetext{
${ }^{6}$ Orji, The Journey so far, 7.

${ }^{7}$ Bebey, African Music, 3.
} 
sustained by the messages in their lyrics. Often, through their songs, the band members developed new Igbo idioms with their lyrics, which today are embedded in Igbo language as hybrids.

This study examines how bongo artists have functioned as social commentators and shapers of culture. The bongo highlife musicians of the 1970s were remarkable in their expressions of the depth of Igbo thought processes. 'Igbo thought process', says Achebe, "does not float on water. It is very deep. It is not a tune you dance to, holding snuff in your palms." ${ }^{\prime 8}$ There are many other adages today that are the creations of the artists. Their popularity and effectiveness have become the bedrock for the revitalization of bongo music in the first decade of the twenty-first century. Popular bongo highlife artists like Sunny Bobo and Chima Eke, began their careers and immediately shot into stardom by recasting bongo highlife music of the 1970s. It is within this understanding that this thesis analyzes the bongo musicians as social commentators, despite their negligence in the society.

One can argue that bongo musicians could not have been studied and given academic and intellectual attention because the musical artist in Igbo society was generally considered lazy, carefree and light-hearted. He could not be taken seriously as an agent of social ideology, despite the fact that the pre-colonial Igbo society cherished its musical artists. This mentality could be felt in Igbo society in recent times; for, it is only in the past ten to fifteen years that Igbo parents began to agree (reluctantly) to their children studying music at the university. Today, many still find this change very

\footnotetext{
${ }^{8}$ Achebe, Echi di Ime: Taa bu Gboo (Odenigbo Lecture; my translation from Igbo), 50.
} 
difficult. ${ }^{9}$ Achebe ascertains this in Things Fall Apart with the story of Unoka, Okonkwo's father who lived on borrowing because he was a 'lazy' musician who could not farm like his peers, and also was not able to take any title. ${ }^{10}$

The focus of this research is to retrieve aspects of Igbo social commentaries in resistance to cultural hegemony, that have been reserved in songs and proverbs and that have not yet received due attention. This research specifically explores how language, instrument and lyrics are used as tools for the resistance of cultural hegemony. It analyzes the lyrics that address decolonization, unity, social justice and family relations. Moreover, it seeks to underscore the relationships between culture, arts, education, politics and society. Artists are in a very good position to change society by active participation in politics, and they can really contribute to socio-political ideology. Of good interest was the fusion of folk songs with other elements of Igbo traditional theatre - dance, masquerade, and games - with the Western dramatic pattern to make a statement against cultural hegemony.

\section{Statement of Problem/Limitation of Study}

This research focuses on bongo music, which is a musical genre of the Igbo people, who live in and around Owerri town, in the Southeast of Nigeria. It is not a work that studies the entirety of Igbo music; Igbo music has a wider spectrum and requires numerous resources to accomplish. Again, even though it would be astounding to study

\footnotetext{
${ }^{9}$ According to my father, when I left Accountancy after two years of study and changed my course to Music Education, he said: "I counted her off." "Counting me off' was not only because musicians were considered wayward but also that music is not seen as a stable means of livelihood.

${ }^{10}$ Achebe, Things Fall Apart, 4-5.
} 
as many of the bongo artists as possible, it would be a very difficult task. Such research therefore, will not be possible because of time constraints. Part of the difficulty is that the research is being done from a distance and relies on audio compact discs and secondary materials. The researcher thus analyzes songs without direct communication with the artists. Some of the songs and albums needed for the analysis may not be easy to locate and might require distant journeys to places like the Nigerian National Archives, Enugu and the radio broadcasting libraries. It will therefore be financially demanding to procure the materials from Nigeria. Thus, only those artefacts that are easily accessible are used.

Having stated the purpose, statement of problem and limitation of this study, this research addresses the following questions:

Beyond the functions of music

- How effective are the Igbo musicians in addressing socio-political and moral issues in society (resisting cultural hegemony and promoting unity)?

- To what extend could bongo music provide an insight into Igbo indigenous philosophy and way of life (family relations and social justice)?

\section{Research Approach and Methodology}

The research is designed to answer the questions raised above concerning the contributions of the bongo artists and music in shaping the culture of the society. Oti's (a writer) treatment of Fela showed the musician's contribution to society and politics through his music but bongo artist are not recognised by scholars.

In addressing the questions raised concerning bongo musicians, this study explores how two bongo musicians uses the Igbo language, traditional instrument and 
lyrics to resist cultural hegemony. It identifies ten songs and analyzes their lyrics. These songs belong to two different bongo musicians. Nze Dan Orji a well-known older artist who adopts a more traditional form of music and lyrics, and Chima Eke a younger artist who adopts a more contemporary form of music (highlife) and lyrics. The two artists represent two different generations of musicians (1960s-1980s and 1990s-2000s).

Reviews of literatures as well as archival materials, newspapers, government gazettes, and autobiographies are also used in this research to support information on the historical background, how music affect the life of African in general, and the Igbo in particular from cradle to grave.

\section{Structure of the Thesis}

In chapter two, the history and culture of the Nigerian and the Igbo people respectively, are discussed. The reason for this historical background is to provide the background for a better understanding of the bongo music, which is the indigenous music

of the Igbo people. It enables us to locate the musical genre both in time and space and be able to identify its contributions to Igbo life and culture.

In chapter three, the nature and functions of bongo, Igbo, Nigerian African music and lyrics in general, are explored, stressing the role of musical lyrics in the life of Africans from cradle to grave. It also exposes how Africans especially the Igbos react to their music. Bebey has observed that much of African music depend on speech. ${ }^{11}$ In other words, songs or lyrics are very essential to African music. It further discusses the music of the Igbo people and the history and nature of bongo music and analyzes how beyond

\footnotetext{
${ }^{11}$ Bebey, African Music, p.119
} 
just entertainment, it functions as a medium for social commentary in society. It also argues that bongo music is not only about hip-wiggling, but also includes songs that make bongo music more popular than the instrumentation.

Chapter four is the theoretical discourse and debate. It explains the theoretical lens used in the analyses which include culture; colonization and hegemony in general. To explore the impact of colonization on African music and culture, it addresses the music in the pre-colonial, African, the cross currents between the Africans, home and the Diaspora and the recent trends in African music. Chapter five explains the methodological approach, methods and techniques, and how data was collected and analyzed in this research. The reliability, validity and limitations of study are also discussed.

Chapter six is the data findings chapter. It states the biography of the oldest and a new generation bongo musicians, Nze Dan Orji and Chima Eke. It explores and analyzes lyrics of ten selected bongo songs showing how effective they are in resisting cultural hegemony and in addressing socio-political, moral issues as well as family related issues in the society. Further analogies are made, explicitly stating the extent in which bongo music provides insight into Igbo indigenous philosophy and way of life; the contributions of the lyrics and ideology intellectually, and how they bongo musicians are able to address some issues that engage scholars till date without getting formal higher (college) education. Chapter seven is the concluding chapter and summary. 


\section{CHAPTER TWO}

\section{HISTORICAL BACKGROUND OF NIGERIA}

In order to understand the role of Igbo Bongo musicians as social commentators, it is important to briefly introduce the Nigerian people and their culture including the Igbo people who are one of the major ethnic groups in Nigeria. The primary aim here is to briefly relate the history and diverse culture of Nigeria and that of the Igbo.

\section{History and culture of Nigeria}

Nigeria, the most populous country in Africa was created out of European colonization in 1914 when the North and South were amalgamated by Sir Fredrick Lugard. ${ }^{12}$ It is a country of different nationalities and ethnic groups. Within its boundary were the great kingdoms of Kanem-Bornu, the Sokoto Caliphate, Ife and Benin, the Yoruba Empire of Oyo, the cities of Niger Delta, the Igbo of the south-east, and the small tribes of the Plateau, including a multiplicity of tribes. ${ }^{13}$ The name 'Nigeria' was coined by Flora Lugard, the wife of the British colonial administrator and it was taken from the Niger River running through the country.

Nigeria is located in Western Africa on the Gulf of Guinea on the Atlantic Ocean and has a total area of 923,768 kilometers square $(356,669 \mathrm{sq} \mathrm{mi})$. Being the world's $32^{\text {nd }}$

\footnotetext{
${ }_{13}^{12}$ Crowder, The Story of Nigeria 19.

${ }^{13}$ Crowder, The Story of Nigeria, 19.
} 
largest country after Tanzania and the most populous country in Africa, it is comparable in size to Venezuela and is about twice the size of California. It has an estimated population of over $150,000,000$ people. It shares a 4,047 kilometers $(2,515 \mathrm{mi})$ border with Benin (773 km), Niger (1497 km), Chad (87 km), and Cameroon (1690 km), and has a coastline of at least $853 \mathrm{~km}$.

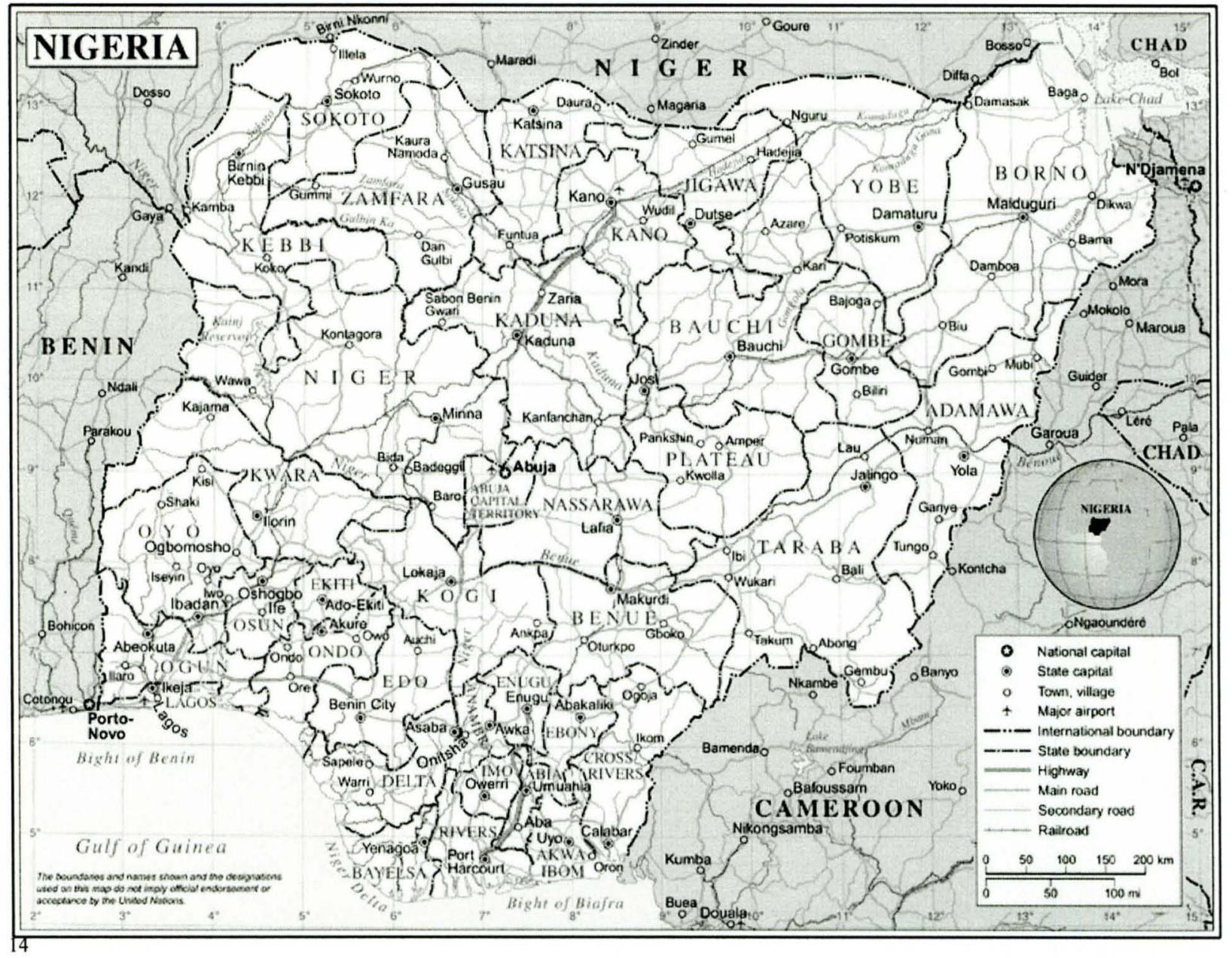

Nigeria, comprising of 36 states and its Federal Capital territory, is a country with rich cultural diversity. After its independence in 1960, the capital of Nigeria was moved from Lagos, the largest city in Nigeria, to Abuja, the federal capital territory, on December 12, 1991. However, to this day, Lagos remains the commercial hub of the

${ }^{14} \mathrm{http}: / /$ commons.wikimedia.org/wiki/File:Un-nigeria.png 
country. Nigeria is made up of over 200 ethnic groups speaking more than 250 languages with varying customs, thereby creating rich ethnic diversity. English, which is the official language, is spoken alongside the indigenous languages. ${ }^{15}$ The largest ethnic groups are the Fulani/Hausa, Yoruba and Igbo, accounting for $68 \%$ of the population, while the Edo, Ijaw, Kanuri, Ibibio, Ebira, Nupe and Tiv comprise 27\%; other minorities make up the remaining $7 \%$. The rivers - Niger and Benue - come together in the center of the country creating a ' $\mathrm{Y}$ ' that splits Nigeria into three regions and in some place, marks the boundaries between one ethnic group and the other. The Hausa are mainly in the North, the Yoruba in the Southwest and the Igbo in the Southeast and West of the river Niger. The ethnic groups in Nigeria have different ancestral histories and these histories follow vastly different paths.

Like other nations, Nigeria can be identified with some national symbols. The main national symbol is the flag, which is divided vertically into three equal parts in which two green sections flank the white section in the center. The green color stands for agriculture while the white represents unity and peace. There are also the national coat of arm, the national anthem, the pledge and the motto, which reads: Peace and Unity, Strength and Progress. Though there are national symbols in Nigeria, the impression one gets from the populace is that there is little or no feeling of national unity. Nigerians prefer to be identified with their ethnic groups as in the pre-colonial times.

Arguably, one can say that the unpatriotic feeling towards Nigeria by majority of its citizens is due to the fact that there is no culture one can point and refer to as 'Nigerian' culture. The only cultural element binding Nigerians is the foreign language,

${ }^{15}$ Falola, The history of Nigeria, 5. 
'English', being the lingua franca and the only language common to most people in the country. The use of this language is one of the effects of colonization and the amalgamation of Nigeria. The English language is used in all government interactions and in government schools. To explicitly discuss Nigerian culture, distinctions among the different national and ethnic cultures will have to be made.

Hausa language is dominant in the north while the Igbo and Yoruba languages are dominant in the south. In principle, they are considered the 'unifying languages' in the north, southeast and southwest respectively, regardless of other languages. Today, all the other ethnic groups especially in the south tend to communicate in English more than the ones designated as 'unifying' languages because of ethnic politics. The minority groups do not consider themselves as minority groups anymore; they either speak their language or the English language. Pidgin (also known as broken English) is also common throughout Nigeria. It is basically a mixture of English and the Nigerian languages and it evolved from the need for the sailors to be able to communicate with the local merchants during slavery. Presently it is commonly used for communication amongst Nigerians who do not have formal education in English language.

There are three major groups of religions in Nigeria: Christianity, Islam and traditional/indigenous religion. The northerners (Hausa) are mostly Muslims; the Igbo mostly practice Christianity and a few still practice traditional religions, while the Yoruba practice traditional religion, Christianity and Islam. Traditional religion involves system of rituals in reverence to the ancestors and in worship to the gods. ${ }^{16}$

${ }^{16}$ Falola, Culture and Customs of Nigeria, 33. 


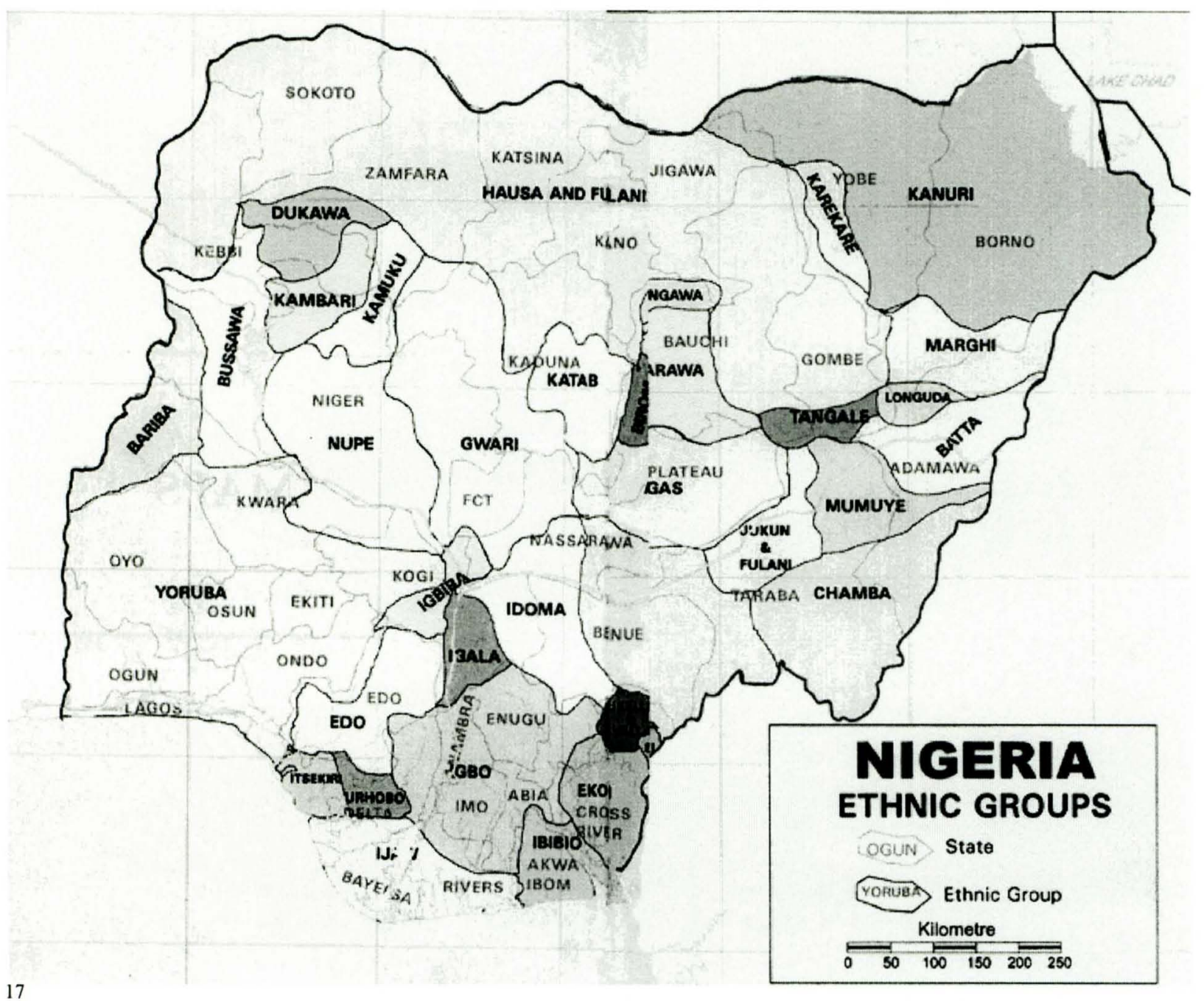

The three main environmental regions in Nigeria, savanna, tropical forests and coastal wetlands greatly affect the cultures (especially food) of the people who live there. The dry open grass of the savanna make cereal farming and herding a way of life for the Hausa and the Fulani while the wet tropical forests in the south are good for farming fruits and vegetables which are mainly produced by the Igbo, Yoruba and the other ethnic groups in the south. Food varies from culture to culture but most Nigerian cuisine is generally based around a few staple foods accompanied with soup. Yams, rice, cassava,

${ }^{17} \mathrm{http}: / / \mathrm{www}$. onlinenigeria.com/mapethnic.asp 
corn, millet, sorghum and sweet potatoes form the basic diet while fruits, vegetables and meat are used for soup or stew. Food is traditionally eaten with hands ${ }^{18}$ although, with the growing influence of Western culture, a good number of people tend to eat with forks, spoons and knife, even in the remote villages. A good percentage of Nigerians who live in the cities could be said to have transformed their eating habits: they seem to prefer the canned, frozen and pre-packaged foods found in the Western supermarkets.

Families in Nigeria are social institutions with its members either related by blood, marriage or adoption; they mostly work together and support each other. Each family is identified by its name, title or their contributions to the society. ${ }^{19}$

\section{History and culture of Igbo people}

The Igbo people are one of the three major ethnic groups in Nigeria and it is currently situated in the Southeastern part of Nigeria. The heartland of the Igbo is located in the central Bights of Benin and Biafra. Among Nigeria's ethnic groups with different languages, economy, and systems of government, the Igbo are one of the three largest groups. The other major ethnic groups include Hausa-Fulani, and Yoruba. ${ }^{20}$ The Igbo are, today, found in seven states out of the thirty-six states of Nigeria, namely: Abia, Anambara, Delta, Ebonyi, Enugu, Imo, and Rivers. Through migration and slavery, the Igbo people are also found in good numbers in other parts of Nigeria, Africa and every part of the world. ${ }^{21}$

${ }^{18}$ Falola, Culture and Customs of Nigeria, 97.

${ }^{19}$ Falola, Culture and Customs of Nigeria, 118.

${ }^{20} \mathrm{Njoku}$, African Cultural Values, 4.

${ }^{21}$ Ekechi, Tradition and Transformation in Eastern Nigeria, 1. 
Traditionally organized in villages, the various Igbo groups share a common history, language, religious beliefs, climate condition, occupation, social organization, political structure, cultural features and can trace their descent from a common ancestry. The Igbo people share a common culture notwithstanding minor differences in the various communities. The customs, language, history and patterns of social organization are similar. $^{22}$

The Igbo language is the language of communication throughout these seven states and there are smaller subgroups and local communities which are marked with dialectal and cultural differences in accordance with clan, lineage, and village affiliations. Each community has their own dialect and each dialect reveals the community/village one comes from. ${ }^{23}$

Politically, the Igbo are organized loosely in small lineages and villages with a tradition of indigenous republicanism and life in the villages appear engaging. ${ }^{24}$

No definite studies to determine the degree and context of segmentation in the lineage structure have yet been made. When the lineage group is small it is invariably exogamous, but this is not always the case with the larger and more dispersed lineages. Each lineage of whatever scale is subject to the moral authority of an okpara - the head of the senior branch in larger lineages - who holds the lineage ofo (a staff symbolizing the authority of the ancestors) arbitrates in internal disputes and represents the group in its external relations. ${ }^{25}$

Among the various occupations in Igbo land, farming is mostly common. Most Igbo are farmers; even traders hold lands and take part in farming. There are individual and group farming. In the latter people help each other through sharing of crops and division of labor. In the highly populated areas and burn out soil, crops like yams and

${ }^{22}$ Njoku, African Cultural Values, 7.

${ }^{23}$ Forde \&Jones, The Ibo and Ibibio-Speaking Peoples of South-Eastern Nigeria, 11.

${ }^{24}$ Basden, Niger Ibos, 147.

${ }^{25}$ Forde \& Jones, The Ibo and Ibibio-Speaking Peoples of South-Eastern Nigeria, 15. 
cassava are the main staples which dominate farming. ${ }^{26}$ The Igbo women mostly engage in trade and their husbands appreciate the hard working ones. Men always choose energetic women for a wife to help themselves and the children and also attract other women's envy. The harder a woman works, the more she is being appreciated by her husband and the community as a whole. ${ }^{27}$

Igbo people believe in their chi (God). In Igbo land, traditional religion follows the Igbo from cradle to the grave. Every aspect of life has a chi that is in charge from conception to death. The converted Christians also carried the zeal with which the Igbo revere reference their gods and ancestors to Christianity; this has made them become more Christians than Westerners who brought Christianity. Igbo people believe that every human being has his/her own chi which takes control of everything ones does from birth to death. The chi determines the destiny of the person; therefore, faults and good or bad fortune as ascribed happens as the $c h i$ wants. People build shrine for their chi in other to keep it safe and offer sacrifices and also ask for assistance in achieving desired ends. ${ }^{28}$ They develop thoughts about all visible things as empowered by nature and regard them as equivalent of invisible forces. Hence the tendency to adore all visible phenomena like trees, rivers, forests, caves and even rock exist and they are believed to have their own gods and goddesses. ${ }^{29}$

The Igbo produce a wide variety of art including traditional figures, masks, artefacts and textiles. Each art work has a historical background and what it stands for. Art, music, dance, cuisine, language as well as their attire are integral parts of the Igbo

\footnotetext{
${ }^{26}$ Forde \&Jones, The Ibo and Ibibio-Speaking Peoples of South-Eastern Nigeria, 13.

${ }^{27}$ Basden, Among the Ibos of Nigeria, 90.

${ }^{28}$ Forde \& Jones, The Ibo and Ibibio-Speaking Peoples of South-Eastern Nigeria, 20.

${ }^{29}$ Agbasiere, Women in Igbo Life and Thought, 49.
} 
life and culture. Because of the subgroups, the variety of Igbo culture is heightened further with the brand of music they produce. 


\section{CHAPTER THREE \\ MUSIC IN AFRICA}

This Chapter explores the nature and functions of Nigerian, Igbo, bongo, and African Music in general. Most indigenous African music which bongo music is one of them, involves songs, instrumentation and dance working simultaneously. There are chants (songs) which are used in reverence to the gods as well as instrumentations (drums and wood drums) which are used specifically for communications. This chapter further states how music forms part of the life of an African from cradle to the grave; from birth (naming ceremony, lullaby) to recreation and moral purposes for children, moonlight games, puberty and initiation, religion, occupation, war, love and courtship, marriage, festivals, social events and entertainment) to death.

\section{Music of Africa}

Music is found in every known human culture, past and present, varying widely between times and places. Music and dance are intimately associated with African life. Among other things, African music brings life to religious worship and rites of passage ceremonies and heralds masquerade plays and carnival dances.

The integral idioms of music, religion, art, dance and especially song-text in the lives of people of African descent is a legitimate sphere of intellectual production. The idea is that music and dance are art forms and practices; they also reflect communicate 
age-honored intellectual ideas. The artist or singer who composed the songs and poems of the festivities, the dancer who moves to the rhythms and the elders that endorse the song for personal or group festivals or ceremonies; all must be understood as producers of texts. Their philosophical ideas deserve more than a casual attention; a more insightful interpretation is necessary in other to appreciate the unique wisdom and value constructs packaged in the idioms of singing and dancing. This chapter provides and interprets some genres of African music (songs), including incantations often encountered in forms of words of wisdom, puzzles, poetries, proverbs and historical narratives. The ethnographic and anthropological results are presented in their historical eras: pre-colonial, Diaspora, colonial and post-colonial forms.

\section{Characteristics of African Music}

Africa is a great continent "but the sounds of Africa are the most wonder-filled things of all. ${ }^{30}$ African music is the music of the indigenous peoples of Africa and it is an embodiment of the indigenous patterns of philosophical expression. Its characteristics include repetition, call and response, variation and contrast. In Africa, music is an integral part of people's lifestyle and serves as an expression of art and aesthetics from birth to death. Music is vital in everyday lives of people and their leader; in Ghana for instance, if you are a chief and cannot dance to the way of your people, you can be dethroned. ${ }^{31}$ Music is therefore an integral part of human culture, as well as instrument for nation building.

\footnotetext{
${ }^{30}$ Warren, The Music of Africa, 1.

${ }^{31}$ Asante, African Dance, 13.
} 
African music and dance accompany each other to mark all aspect of human life and existence. Dance synchronizes with the music. Every stage in life cannot pass by without music and dance contributing immensely to the success in the transition in terms of history, worship, communication, and entertainment as well as inculcating moral/social beliefs and values as transmitted to the younger generation. It is not out of place to say that African dance is based upon the spoken language, and a source of communication through which it is possible to demonstrate emotion, sentiment, beliefs and other expressions through body movements. ${ }^{32}$ Music is very important because it passes down tradition and was the principal mode of cultural transmission before the introduction of Western form of education and literacy.

Music serves as a useful tool to bring members of a community or communities together in the celebration of events. It cements ties which community members have for one another. Chinua Achebe captures this sense of community in his comment that "the crowd surrounded and swallowed up the drummers, whose frantic rhythm was no longer a mere disembodied sound but the very heart beat of the people. ${ }^{33}$ Thus, music provides an outlet through which people ease off stresses of everyday life. Above all, music provides sources of pleasure and revelry for the African, as often embodied in folk songs and dances.

\section{African Folk Music}

Folk music/songs and dances are time-honored form of traditional music. Styles of folk music are adapted and related to the different ethnic groups in the continent. As

${ }^{32}$ Asante, African Dance, 13.

${ }^{33}$ Achebe, Things Fall Apart, 43. 
one moves from one region to the other, one encounters each group with its own techniques, instruments, and songs. Folk music has been defined in several ways; as songs that are traditionally sung by the common people of a region, area or community which form part of their culture; as music transmitted by word of mouth, and also as music with no known composer. Folk music is usually a call and response form of music. It is passed from generation to generation through oral tradition. They are used to inculcate social beliefs and moral values, which infuses and enriches culture. Folk music commemorates festivals, historical and personal events and is not usually meant, in the original context, for commercial use. In fact, folk music is originally owned by the communities that produced them. To understand the contemporary music in Africa, it is crucial to have the knowledge of the lyrics of folk music in its social context, to gain more insight as to how it relates to the African in his personal and social life. ${ }^{34}$

\section{Music of the people of Nigeria}

The music of Nigeria includes traditional/ folk and popular music. The folk or traditional music connect with the different ethnic groups in the country, each with their own instruments, style and song lyrics in their respective languages. The lyrics of songs are considered most important because of the role songs play in society as means of communication. Oti ascertains this in describing highlife music which evolved from the traditional music of Nigerians and Ghanaians:

Its dynamism does not lie in the aesthetics of its form and style, as a dance music relying almost totally on Western musical instruments; it lies more on its song-texts. ... Highlife musicians may be referred to as modern

\footnotetext{
${ }^{34}$ Nketia, The Music of Africa, 20.
} 
African town criers whose message or song-text, like drama and theater texts, presents not only Africa's culture but her social, economic and political problems. ${ }^{35}$

Highlife or palm wine music which is one of Nigeria's popular music, is a hybrid of traditional music and Western instruments. Some of the music include apala, juju, bongo, fuji etc. Nigerian musicians created their own styles of the United States hip-hop and the Jamaican reggae. Presently the hip-hop and gospel are very popular in Nigeria and Africa as a whole. The musical output of Nigerians has achieved international acclaim not only for popular music and folk but also for Western art music by composers such as Fela Sowande. The success of Nigerian music is attributed to its cultural diversity and the people's creativity. The desire for aesthetic and appetite for music, create enough room for more artists who sing in regional languages and experiment with indigenous style. Each of the ethnic groups owns their own styles of music. The Igbo being one of the major ethnic groups have different genres because of their popularity and diverse culture.

\section{Music of Igbo people}

Igbo music is the indigenous music of the Igbo people and it has been in existence as long as the Igbo man has existed. Music is part of the life of every Igbo person and it is incorporated into almost all the facets of their daily lives. Music and dance are interwoven and Igbo music is generally lively, upbeat and rhythmical; and there would always be dancing when music is being played with people singing and dancing in response to the lead singer and rhythm. The Igbo is believed to be gifted with

\footnotetext{
${ }^{35}$ Oti, Highlife Music in West Africa, 1.
} 
a sense of rhythm and rhythmic complexities, which is different from European music. ${ }^{36}$ They are very creative in rhythm which calls for dancing displays; once the music starts playing, everyone starts moving in accordance to the rhythm, the sounds are excellent for dancing purposes.

Igbo music is unique and relies heavily on percussive instruments. The ogwe (drums) and the ogene (gong) are the most important in the indigenous music of the Igbo people because they give rooms for improvisation and accompaniment and bestow Igbo music with its peculiar timbre and pitch. Some other important instruments include the $u d u$ (pot drum), which is typically dumb-bell shaped, is metronome instrument used to produce bass; the ekwe (slit drum), which is constructed from a hollowed out palm, bamboo, or pear tree trunk is used for signalling an emergency, community meetings, or warning of intruders' presence in most Igbo villages. Okwa (wood block) ichaka (rattle) and oja (flute) are also substantial in different styles/genre of Igbo music.

\section{The Communal Nature and Functions of Music in Igbo Society}

In his renowned novel, Things Fall Apart, originally published in 1958, Chinua Achebe left the reader with a graphic picturesque of the place of music as a mode of communal expression and identity. He likened the sound of drums to the lives of the villagers as the pulsation of its heart; when it sounds in the air, it spreads like wind; in the sunshine, it blossoms; even trees and lands feel the impact. ${ }^{37}$ In this description of the drumbeats for the wrestling match, Achebe captures all there is to say about the place of African music in a traditional African society. In Igbo, music is not only an inspirational

\footnotetext{
${ }^{36}$ Basden, Niger Ibos, 356.

${ }^{37}$ Achebe, Things Fall Apart, 31.
} 
and vital art form but is also known to catalyze communal spirit among the people. Ifionu observes that Igbo music produces the spirit of oneness; and the love for music and zeal with which it is practiced, not only entertains but also unify and consolidate all the Igbo people living in the same community. ${ }^{38}$

The power which traditional Igbo music possesses to engender communal unity derives from the fact they were not owned as an individual property but rather held as a communal or collective property. In the indigenous society songs and music were not distinct from the communities that generate them. In other words, the music that comes out of any Igbo community or any African society for that matter tells something about the language, history or lifestyle of that community and therefore is an integral part of that community's identity.

Igbo dance performs the same functions, for example, there is the war dance that tells the warring history of the people of Ohafia, Bende, and Ngwa of the Eastern parts of Igbo land. The erotic hip wiggling of kelenkedimma, Agbachaa e kuru nwa or Nkwa di $k w e r e$ nwaanyi (generally known as Egwu Ukwu - hip dance) or more recently, Egwu Owerri (Owerri dance) of the Owerri and Ngor Okpala areas tell of their inclination towards a hassle free life; the showing off steps of Egwu Ogaranya and Igba Ndi Eze of the proud and title loving Onitsha area, and so on. Some of these varied dance traditions like the war dance of the Ohafia, Bende and Ngwa people, troubled colonial administrators in the Igbo area and as such were closely studied and classified as either 'harmless' or 'harmful' in accordance with whom was doing the dancing, when, how and

${ }^{38}$ Ifionu, "The Role of Music in Igbo Culture: An Ethno musicological Explanation," 44. 
for what purpose. ${ }^{39}$ So, Basden is not mistaking in his observation of Igbo dances when he observed that the dances are different and they serve different purposes for various communities. ${ }^{40}$

Like in other items of material culture, Igbo towns and communities traded their music with each other on regular basis making Igbo traditional music next to language in unifying the Igbo nation. In Things Fall Apart, Achebe observes that Unoka, Okonkwo's father, and his dance group were always invited by other villages to stay with them and teach them their dance. ${ }^{41}$ Through music and dance, therefore, communities shared in the lives of one another.

Like every other art form in the traditional society, Igbo traditional music is meant to be at the service of society. This is why Achebe, insists "that art is and was always, in the service of man. ${ }^{, 42}$ Artists in the pre-colonial Igbo society, including musicians, he observed, lived in various villages in Igbo land, moved around to neighboring villages for entertainments and businesses, had their being in society and created their works for the benefit of the people in the society. ${ }^{43}$ Igbo music, songs, instrumentation and dance, not only played an important in the Igbo community but also in the broader Nigerian society.

\section{Lyrics and Ideology}

The lyrics of Igbo modern music are also culturally informed and aim at serving society through social commentary. In the first place, the language of the Igbo Highlife

\footnotetext{
${ }^{39}$ National Archives of Nigeria Enugu (hereafter NAK), AWDIST 2/1/56 Dances harmful or otherwise report on, 1919.

${ }^{40}$ Basden, Niger Ibos, 344.

${ }^{41}$ Achebe, Things Fall Apart, 4.

${ }^{42}$ Achebe, "Africa and Her Writers" in Morning Yet on Creation Day, 25.

${ }^{43}$ Achebe, "Africa and Her Writers" in Morning Yet on Creation Day, 25.
} 
musicians was and is Igbo, except that once in a while, a certain musician may choose to have a track in English like Joe Nez's 'Business Trip' or in the fashionable Pidgin language like Herbert Udemba's 'Bottom Belle.' Using Igbo language has remained the most preferred language of expression because it helps the contemporary musicians to continue the poetic and ideological trends in traditional music which has made them notable for Igbo idioms, proverbs, and parables.

\section{History and Nature of Bongo Music}

Bongo is a type of ogwe (drum) which produces high-pitched sound and bongo music is dominated with set of bongo drums with other percussive instruments accompanying them. Bongo is a percussion instrument and it belongs to the family of membranophones in the classification of African musical instruments. The membrane is made up of animal skin and other is wood; "it may be conical, cylindrical, or semi cylindrical, with a bulge in the middle or a bowl-shaped top, cup-shaped, bottle shaped, in the form of a globe or vase, or in the shape or an hourglass; the frames may be round or square., 44

Bongo drums are usually played by men; mostly young and middle aged men, and few old men. Bongos could be played while seated or in a standing position with the drums held between the legs or place in front on a drum stand. The bigger drum also known as male drum is usually on the drummers left while the smaller or female drum is on the right. ${ }^{45}$ There are also drum stands where the bongo drums are placed while being played. Most times the tone of the drums determine where they are placed while playing

\footnotetext{
${ }^{44}$ Nketia, The Music of, 86.

${ }^{45}$ Salloum, The Bongo Book, 2.
} 
and the techniques applied to particular drums depend on the sonorities of the drum in mind. Some drums are played with sticks of different sizes while others are played by hand, or stick and hand combined. ${ }^{46}$

The sound of bongo drums is closely associated with Owerri people of the Igbo community. Bongo music instrumentation is a combination of bongo drums that result in an upbeat form, played along with percussive instruments. The lyric of bongo music is of most importance as well as instrumentation and the accompanying dance (hip wiggling). Songs, instrumentation and dance make up the bongo music. Singers perform a different function than the instrumentalists ${ }^{47}$ because they convey messages with Igbo-Idiom and some spiritualist preach the gospel through this media. The Igbo people and African in general enjoy gospels when they are preached musically. ${ }^{48}$

Although historically Bongo had been identified as the indigenous music of the Owerri which was only played with the traditional instruments, it lost popularity in the 1960s because of the Nigerian civil war (1967-1970) and re-emerged shortly after the Nigerian civil war in the 1970s carrying mostly the same elements of highlife music (rhythm, traditional and Western instruments, dancing and lyrics), but with bongo drums as lead instruments. Today, the bongo drum has become a dominant instrument in Owerri music to the extent that Owerri music in the past four decades is known as Bongo music. Naming a type of music after an instrument reflects the important role the instrument (drums) plays in African music.

\footnotetext{
${ }^{46}$ Nketia, The Music of Africa, 89.

${ }^{47}$ Oti, Highlife Music in West Africa, 129.

${ }^{48}$ Oti, Highlife Music in West Africa, 121.
} 
It is difficult to trace the particular community/place where bongo started in Owerri, as people hold different histories of origin of their own bongo music. Dan Orji, one of the oldest modern bongo musicians in Owerri says:

At the end of the war, I organized a bongo group and christened it the 'boy friends', which metamorphosed into the Peacocks International Guitar Band. I met Raphael Amarabem in Owalla, Uratta, at a naming ceremony of Mr. Aloysius Oduobi's child. He performed so wonderfully that I was moved. I congratulated him on his marvellous performance. Ralph and I then agreed to work together to Orji and started the joint musical journey that saw the birth of the Peacocks International Band from the 'boy friends'. ${ }^{49}$

Sarowiwa a modern bongo musician ascertains this in his music 'Sarawiwa Apalila Egwu' (Sarowiwa has started his music), were he refers bongo music as a good, nice and a heavy music which was passed from generation to generation. He started playing and dancing to bongo music as a kid in his kindred with his brothers during the moonlight games and, therefore, bongo music existed before he was born. Sarowiwa asserts that there was atilogwu (a genre of Igbo music) along side with bongo music. He concludes the he is still playing the bongo and his bongo music is like loud in the sky; and as long as "the cloud remains so shall his music remain."

Bongo music is now the most popular music in Owerri and Imo State of Nigeria as a whole. The Owerri man who is considered to be "musical by nature" has been able to contribute a lot to the Nigerian entertainment industry ${ }^{52}$ and also has passed bongo music from generation to generation to date.

\footnotetext{
${ }^{49}$ Orji, The Journey so far, 7.

${ }^{50}$ Jacobs (Hereafter 'Sarowiwa') Sarowiwa Apalila Egwu in Bongo Jere Uzo Ije (2005).

${ }^{51}$ Oti, Highlife Music in West Africa, 111.

${ }^{52}$ Orji, Owerre in the Twentieth century, 164.
} 


\section{Functions of Music}

African music is categorized according to its function and phases of community life in the African society; most of it serves for more than one purpose, for instance, a lullaby comforts a baby and also educates a child on the reasons why he/she should not cry. ${ }^{53}$ African music is all about life expression through music and its musicians make it realistic rather than only seeking to combine sounds in a manner that is pleasing to the ear. ${ }^{54}$ Music follows the African through his entire day right from the morning till late at night, and through all the changes of his life, from the time he came into this world until death, and even long after he has left it. ${ }^{55}$ Special songs are made for each occasion and each is imbued with important moral lessons and social values. Men and women, young and old receive morals lessons through songs and dances. They also learn their history, customs and responsibility which will guide them all through their life time. Nketia affirms this by exploring the music of the Arabic nations in Africa and concludes that:

Music accompanied the Arab from cradle to grave, from lullaby to elegy. Every moment of his life seems to have had its particular music - joy and sorrow, work and play, battle-throng and religious exercise .... Vocal music has always been more keenly appreciated by the Arab than the purely instrumental music. Their ardent taste for poetry determined this to some extent, although the pressure of legal opinion which frowned on instrumental music per se also contributes to the preference . . . . There were also instrumental pieces, but far oftener they were used as preludes or interludes to vocal items. ${ }^{56}$

Generally, the kind of music that may be performed at an occasion depends on the social event and those involved in it. It is customary to organize the music in relation to the

\footnotetext{
${ }^{53}$ Bebey, African Music, 6.

${ }^{54}$ Bebey, African Music, 3.

${ }_{55}^{55}$ Warren, Music of Africa, 3.

${ }^{56}$ Nketia, Music of Africa, 12.
} 
different phases of community life or in terms of the need for special situation. ${ }^{57}$ Below are examples of Igbo songs that illustrate how African music relates to any aspect of life and death.

\section{Birth}

The African child is believed to be naturally gifted for music because at infancy, parents, grandparents, siblings, and friends sing to the delight of the infant. The African child is influenced and socialized with music at a very early age. He begins to make his own musical instrument as a young child; creatively he/she makes rattle out of empty tin and drums out of window-frames and pieces of animal hide (this type of drum is called frame drum) ${ }^{58}$ At this early age, all the child does is to listen and as he/she grows the child begins to participate in music - thus enabling the young talent to unfold. There are songs sang during the birth of any baby; be it a male child, female child or twins. The special songs are for celebrating the birth of a child.

\section{ONYE NO NGA}

Onye no nga

Refrain: Omumu loo nga (repeat)

Nwanyi mma (name of the child bearer) no nga

Refrain: Omumu loo nga

All: Ya wuru nwoke ya hirikwa

Ya wuru nwanyi, ya hirikwa

Ya weta nwa ose fuo onu

Nwa ose fuo onu, nwa agba ala elu o!

[Who lives in here?

Refrain: Let fertility bless this place Nwanyi mma (beautiful Woman) is here

Refrain: Let fertility bless this place

Be it male, let it live

${ }^{57}$ Nketia, Music of Africa, 24.

${ }^{58}$ Bebey, African Music, 6. 
Be it female, let it live

Let them give us something to spicy

Something spicy to make us lift our jaws.]

This kind of performance is mostly done by women in the same kinship of the mother of the born child, though any woman passing by will most likely join in the singing and dancing to rejoice with the people. Among the Igbo people of southeastern Nigeria, the women sing and dance with ululation. They share white powder and $n z u$ (clay) and rob over themselves while singing and dancing.

\section{Naming Ceremony}

This is an important occasion in Africa which is heralded with songs and dances. The mother of the new born child is invited to dance while other women sing and play instruments to the rhythm of the songs.

Olee nwanyi muru nwa ee, nwanyi muru nwa bia were njaa gi zaruo ala, bianu teela anyi egwuoo

[Where is the mother of this child?

Come with your cloth Come and dance for us]

The men surround the father of the child while he names his child. The audiences at such occasions eat, drink, sing and dance until the ceremony ends. Naming ceremonies, like the observance of the appearance of the first tooth are both celebrated in song and dance. ${ }^{59}$

\footnotetext{
${ }^{59}$ Warren, Music of Africa, 4.
} 


\title{
Lullaby
}

This is a cradle song, sung to lure children to sleep. It is usually a soothing song with which to lull a child to sleep and is usually rendered in a quiet tone.

\section{NWANNE M RAHU URA}

Nwanne rahu ura bom, bom bom

Nwanne rahu ura bom, bom bom

Nwanne rahu ura bom, bom bom

Akwa a dighi mma bom bom bom

(Sleep, my sibling, sleep (bom bom bom - ordinary expression) $3 \mathrm{x}$ Crying is not good for you (bom bom bom)

Sometimes, there is an employment of single instrument to accompany the song;

for example the use of rattles to keep the metronome while the singing is going on. Some of the texts of cradle songs may reflect not only themes interesting to the child or musical elements amusing to him, but also references of interest primarily to mothers and adult listeners ${ }^{60}$.

\section{Recreational and Moral Purposes}

Children attempt to imitate elders in all things including music, in singing, dancing and instrumentation. Therefore, music forms the mode of socialization and the basis of children's participation in later lives including respect and honor for parents.

\author{
NWA M ECHEFUKWALA NNE MUQRU GI \\ Nwa m echezokwana nne muru gi, \\ Echefukwala nne muru gi \\ Afufu o tara mbosị ime na eme ya \\ I ma na o riro, i ma na o nưro \\ Na enu echiche ka nne gi raruru \\ Nwa m echezokwana nne muru gi, \\ Chetakwa nne muru gi
}

${ }^{60}$ Nketia, The Music of Africa, 23. 
Turụ zam

Nne muru gi

Turu za m

Nne muru gi

Turu zaza m za m, turu za m za m, turu zam.

[My child, forget not the mother that gave birth to you

Forget not the mother that gave birth to you

Her sufferings during her labor period

Do you know she never ate, do you know she never drank

Anxious thoughts became her sleeping mat

My child, do not forget the mother that gave birth to you

Refrain:

Remember the mother that gave birth to you - turuzam!*

The mother that gave birth to you - ...

The mother that gave birth to you -...]

Thus, children learn faster through songs. For instance, they hear and learn language, norms, values, numbers, history, facts about life, places, events, laws of the community, true life stories, dos and don'ts through songs. At this early stage, the musical games children play are voluntary and complementary; they learn songs and dances which prepare them to participate in all areas of adult activity which include occupations like fishing, hunting, farming, grinding maize as well as weddings and funerals. ${ }^{61}$

\section{Moon Light Games}

This is usually done at night when the moon is out, shining bright. Children and adults gather in different groups at either front of their homes and/or playgrounds to share folktales. The tales mostly involve songs with call and response; most times an adult telling the stories sing while others respond in excitement. Singing and dancing in circles

${ }^{61}$ Bebey, African Music: A People's Art, 8. 
are part of the fun including hundreds of games which made everyone happy. The history, culture and social values are embodied in the stories and songs, mostly framed with the animal kingdom.

\section{AGU NA-ERI EWU ERI}

Agu na-eri ewu eri o - Resp: gwo gwo, onye ekwela agu bata, gwo gwo

(sing many times before going over to the phase with faster rhythm)

O gaghi eri ya-egwu okpu $4 x$

O gugbuola ya-egwu okpu $4 x$

[The tiger is about to eat the goat -

Response: No no, let no one allow the tiger to enter, no, no!

It (the tiger) won't eat it (the goat) - our unchanging dance

It (tiger) is dying for it (goat) - our unchanging dance]

\section{Puberty/Initiation}

In West Africa, music plays a vital role in initiation ceremonies; the ceremony is almost impossible without music having its own defined roles to play. Circumcision rites are performed during this stage where boys are taught songs while waiting for their wounds to heal. The girls go around the villages singing and dancing the puberty songs and dances for some days after the completion of the puberty ritual; the villagers appreciate them by giving then gifts. ${ }^{62}$ Once the above ritual is done by both the boys and the girls, they become set for marriage.

OFEBE (Initiation/Puberty)

Chinedu* efebeooooh,

Refrain: Ofebe ofe muo, ofebe

* Chinedu (name of initiated is used)

(Chinedu is passing over

He is passing over, great one

His passing over)

${ }^{62}$ Warren, Music of Africa, 6. 
Music is important during initiation since it has been a constant factor throughout the child's life. ${ }^{63}$ African music graces initiation ritual which is integral to African culture.

\section{Religion}

Religious music includes sacred music and songs used for religious worship and rituals. Music plays significant role in the religious life of Africans; one can say that religious activities are impossible to comprehend without music. It mostly comes in incantations with the chief priest acting as a mediator between the gods and the people. There are different chants and song to diverse divinities and gods of the people. There are songs to pour libations, songs of sacrifice, songs to appease the gods over a taboo, songs to ask for benevolence before embarking on a project, songs for protection against evil, songs to make the rain fall, songs of praise after receiving a favor from God Almighty, or from the gods as some might think. Since illnesses are believed to have spiritual causation in the traditional belief system, there are also songs for healing both the sick and the mad. It is believed that the mad person loves music and it has a soothing effect on mental health.

\section{EKE LEELE}

Eke leele - Hei! Haya haya haya hei!

Orie leele - Hei! Haya haya haya hei!

Afo leele - Hei! Haya haya haya hei!

Nkwo leele - Hei! Haya haya haya hei!

This is a song of invocation, calling on the gods representing the four market days in Igbo land 'Eke, Orie, Afo and Nkwo', to come and hear the people's prayers.

\footnotetext{
${ }^{63}$ Bebey, African Music: A people's Art, 10
} 


\title{
Occupational Songs
}

In the most African society, work is often manual and communal. Music is made by common people during both their work and leisure. Manual labor often includes singing by the workers, which serves several practical purposes. Occupational songs reduce the boredom of repetitive tasks; keep the rhythm during synchronized pushes and pulls, and set the pace for many activities such as weeding; reaping, threshing, weaving, and milling used for both single and collective work. Some of the domestic works include grinding and pounding. Farming, fishing, wine tapping, builders, clearing paths, building bridges, goldsmith, blacksmith, weaver, plowing songs are typical examples of occupational songs. The boatman sings as he paddles and even the pounding of the pestles in the mortar provides the rhythmic accompaniment to the songs women sing; there by making every sound in traditional Africa relevant and important. ${ }^{64}$ An important occupation is that of wine tapping where usually the following song is sung by people waiting for fresh wine to motivate the wine tapper as he climbs the tree:

\author{
OKU NGWO \\ Solo: Oku ngwo n'eje 'lu je \\ All: o na e nwe anuri \\ Repeat \\ All Continue: Mgbe o rigoro na ngwo ya \\ Ya ewerenu nwa efe ya \\ ịkwa nchiki, ịkwa nchịi \\ o na e nwe anuri \\ chịichịi \\ ikwa nchiki, ikwa nchị \\ o na e nwe anuri \\ When the wine tapper goes up \\ He's filled with joy
}

${ }^{64}$ Bebey, African Music: A people's Art, 11. 
When he climbs up his palm tree

He applies his iron peg

Piercing and shaking, piercing and shaking

He is filled with joy!

Shaking, shaking!

He is full of joy!

War

Wars usually trigger when a particular community offends another by, may be taking a land that belongs to them or kidnapping one of their members. There are also wars to show how powerful warriors are and also the most powerful warrior in the community. The warriors sing motivational war songs while preparing for war. On their way to the war field they sing brave songs moving their hands and feet in unison; when they are coming back, they sing victory songs if they win but when they lose they sing solemn songs like the dirge, probably carrying dead bodies. Warriors or any individual who perform well could be praised with praise songs. For example, a warrior who won battles for the people could be immortalized with songs. These songs serve as a motivational factor, encouragement and one of the weapons the fighters have. ${ }^{65}$

ONYE AKPALA NWAGU AKA N'ODU

Onye akpala nwagu aka n'odu

Ma odi ndu, ma o nwuru anwu.

Don't touch the tiger's tail!

$\mathrm{Be}$ it alive or dead! (the warriors are regarded as tigers)

${ }^{65}$ Warren, The Music of Africa: An introduction, 7. 


\title{
Love/Courtship
}

Couples use music for relaxation; they sang to each in mellow tone while looking into each other's eyes mostly in hidden places. One feels fulfilled when his/her lover sings because the song's memories continue and that is what is remembered till the next meeting.

\author{
CHOBA ONYE GA-ABU OYI M \\ Choba onye ga-abu oyi $m o$, \\ Onye ga-abu oyi mo \\ A fugo mu oyi mo \\ Onye ga-abu oyi mo \\ Searching for who will be my lover $3 \mathrm{x}$ \\ Who will be my lover? \\ I have seen my lover $3 \mathrm{xs}$ \\ The one to be my lover!
}

\section{Marriage}

Husband-wife relationship receives a great deal of attention in African song, from the beginning of the marriage when a man is asking for a woman's hand in marriage till the end, whether it ends well or not (death or divorce). There are songs that portray marital conflict resulting from infidelity, refusal of responsibility or poverty as well as creating awareness for a maiden ready for marriage.

\section{O GINI CHATURU N'ELU}

O gịni chaturu n'elu? - yege-yege, udara asaa, yege-yege $2 x$

Kputum, kputum-yege-yege, udara asaa, yege-yege 2 xs

O gịni chaturu n'elu - yege-yege, ocharuru ocharuru, yege-yege 2 xs

What have we got ripe up there? - (yege yege)* seven peach fruits... Chubby Chubby (full of flesh) $-\ldots$ seven peach fruits...

What have we got ripe up there? - ... it is well ripened... 


\section{Expressions}

A young girl ready for marriage is considered to be ripe as fruit.

Yege-yege - delicately appealing

Kputum kputum - full of flesh, very healthy]

\section{Festivals}

Songs and dances are used to mark the special festivals like coronation, seasons and traditional yearly events. The festivals and the music are inseparable because of the important role music plays in giving Africans the feeling of kingship and loyalty in their

community. ${ }^{66}$ Festive music is organized in different ways; it could be organized as a concurrent activity playing in the background or incidentally while feasts, walking parties, games, wrestling matches, processions and beer parties are going on. ${ }^{67}$

\section{JIKEREWE NU \\ Umu okoro ibe mu \\ Jikerewe nu na hemehem! \\ Ebee ka unu si? \\ Ala-Igbo! A ga'm ahapu Ala-Igbo, gama ebe ozo ga biri \\ Umu-Igbo ga-adi ndu!}

Come on, my fellow young men

Get ready in earnest

Where do you come from?

Igbo land! I cannot abandon Igbo land to go and live elsewhere! Igbo children will live!

\section{Social Events / Entertainment.}

In leisure time, singing and playing of musical instruments were common forms of entertainment and history-telling. Most times, it is used as a medium to communicate

${ }^{66}$ Warren, The Music of Africa: An introduction, 7.

${ }^{67}$ Nketia, Music of Africa, 27. 
to the leaders of the society and they are regarded as a powerful medium through which the oppressed and people who seek for justice convey their messages and express their disappointment, anguish and general feeling about what is going on in the society. ${ }^{68}$

\section{URI OMA}

1. Uri oma lee, lele - uri oma $2 \times s$

Onye na nwanne ya kwuru jee ohị nku n'okpu-ulo - uri oma

O kpacha nku ghara nwanne nke ya o - uri oma

Onye na nwanne ya kwuru gaa egwu atu yaAgamevu ari mma na aju, unu anula

\section{Sweet Music}

Sweet music - sweet song (ref)

Who with his brother went to fetch firewood -?

But leaves him behind in the forest?

Whose company worries his brother? -

Rest not your head on a traitor. Do you hear me?

Chorus: Sweet music...sweet song...

Sweet music

Let no one abandon their sibling - sweet song.

\section{Funerals}

Funeral songs may be classified into dirge and entertainment. Dirge is done before and during the burial while livelier songs and dance are performed after the burial in form of entertainment to console the bereaved. Most times, songs of rebirth are performed to direct the dead where to reincarnate. Songs are used to express how people feel about 'death.'

${ }^{68}$ Ekechi, "The Future of the History of Ideas in Africa," African Studies Review 30, no. 2 (1987): 63-81. 
onwu wu onye oshi,

onwu wu onye oshi

ozuru ogbalaga

Death is a thief,

A run-away thief or an unstoppable burglar

Although African traditional music is still practiced in most rural areas in Africa, the impact of Western culture in music has brought about new idioms that combine the African and Western element in the music of Africa. 


\section{CHAPTER FOUR}

\section{COLONIZATION AND CULTURAL HEGEMONY IN AFRICA}

This chapter generally defines the concepts of culture, colonization and hegemony. It exposes the impact of colonization in Africa, by exploring the music and culture of Africa before colonization and the cross current between the African on the continent and in the Diaspora as well as recent trends.

\section{Culture, Colonization and Hegemony}

Culture could be seen in different ways. Culture has been defined as a body of traditions and experiences that distinguish a specific society. This involves shared customs, languages and beliefs. Secondly, it seeks to reveal peoples identity in terms of retention of traditional culture as well as the assimilation of new culture. This is the general trait found in human beings and it involves being able to communicate, having art, jokes and games, and other fundamental set rules governing human being. Culture deals with human beings in different ways; it could be associated to an individual, a group of people or the whole society. ${ }^{69}$ It is difficult to distinctively state a clear meaning of culture. The definitions given have been either vague or narrow because culture quality depends on the condition of life. ${ }^{70}$ Culture involves those qualities that make man at ease

${ }^{69}$ Eliot, Christianity and Culture, 93.

${ }^{70}$ Cowell, Culture in Private and Public Life, 4. 
with his environment. ${ }^{71}$ Ali Mazrui, on the other hand, defines culture by its functions and he identifies seven functions of culture:

Culture provides lenses of perception, a way of looking at reality; provides standards of evaluation - what is good and what is evil; conditions motivations - motivates people to act or not to act; a medium of communication - ranging from language, through physical gestures to manner of dressing; provides basis for the pecking order in society; influences mode of production and economy; defines identity - determines who are the "we" and the "they" in a given situation. ${ }^{72}$

In Africa, the people's culture held sway, performing these various functions from the Africans' perspective until the colonization of the continent by the West. Colonization involves the conquest and control of other people's land and goods. ${ }^{73}$ Such control, one may argue, could not have come so easy if the people's cultural values remained unchanged. For instance, in the area of religion as Mazrui observed that ...the feminine virtues of Christianity - the softer ideals of love, gentleness, tenderness, forgiveness and patience - were invoked in Africa in a manner which made the "pacification" of Africans easier and their submission to the imperial order speedier. The harder warrior values of Africa - courage, endurance, manhood, and even purposeful ruthlessness - were discouraged ${ }^{74}$

In this way, the colonizer, who also came with Christianity, disarms the colonized and makes him become submissive. In becoming submissive, the colonized is transformed into a self-destructive agent, facilitating the colonizers' hegemonic agenda, which is the erosion of the cultural values of the colonized.

\footnotetext{
${ }^{71}$ Kroeber \& Kluckhohn, Culture , 30.

${ }^{72}$ Mazrui, The African Condition, 47-48.

${ }^{73}$ Loomba, Colonialism/Postcolonialism, 2.

${ }^{74}$ Mazrui, The African Condition, 52
} 
Hegemony involves socio-political domination and the imposition of foreign (cultural) values on the life of a group of people. Hegemony is of great value to imperial or colonial power because it is important for it to maintain dominance over the colonized. According to Antonio Gramsci, hegemony or "the supremacy of a social group manifests itself in two ways, as 'domination' and as 'intellectual and moral leadership'. A social group dominates antagonistic groups, which it tends to 'liquidate', or to subjugate perhaps even by armed force.,"75

In most cases, colonial hegemony provokes resistance and defiance. In many cases, however (where the colonized offers remarkable resistance), the contact (or rather, confrontation) between the colonizer and the colonized brings about a hybrid culture, which still affects the language, art and the people's way of life in general. However, since hybridity does not appear to be the desired effect of its hegemonic rule, the imperialist, as Ngugi wa Thiong'o observes, wields his biggest weapon on the colonized - a weapon he refers to as "cultural bomb." According to Ngugi

The effect of a cultural bomb is to annihilate a people's belief in their names, in their languages, in their environment, in their heritage of struggle, in their unity, in their capacities and ultimately in themselves. It makes them see their past as one wasteland of nonachievement and it makes them want to distance themselves from that wasteland. It makes them want to identify with that which is furthest removed from themselves; for instance, with other peoples' languages rather than their own. ${ }^{76}$

This is the bomb the colonizer unleashed on the African continent and it affected all aspects of the Africans' lives, including the arts. The colonial leadership and dominance over the colonized over the years has caused a considerable loss to Africa in

${ }^{75}$ Easthope \& McGowan, A Critical and Cultural Theory Reader, 43

${ }^{76} \mathrm{Ngugi}$, Decolonising the Mind, 3. 
terms of cultural and social practices, political organization and economy. It is the effort to regain some these aspects of its life that constitutes the postcolonial struggle - a struggle that has lingered from the period of the fight for political independence to the present. Alastair Pennycook is right to point out that "Colonialism and postcolonial struggles have been central to world history over the last two centuries." ${ }^{, 77}$ These struggles he observes

...have produced and reduced nations, massacred populations, dispossessed people of their land, culture, language and history, shifted vast numbers of people from one place to another. And they are also the ground on which European/Western images of the Self and Other have been constructed, the place where constructions of Superiority and Inferiority were produced. ${ }^{78}$

These colonial constructs have been made possible through the use of the colonizer's language. In the case of Nigeria, colonized by the British, colonial constructs - constructions of self and other, of superiority and inferiority have been made possible through the use of English language. That is why Pennycook argues that English Language Teaching produced by the colonial Empire still remains an important tool in the service of the Empire. ${ }^{79}$

In Nigeria, for instance, English language still serves the British Empire by keeping the colonial structure, Nigeria, as one country. Many have argued that without the English language, there would be no Nigeria, for the language makes the constituent nationalities feel that they are one entity. Nigeria as an entity was formulated in 1914 under Lord Fredrick Lugard, bringing different British Protectorates under one

\footnotetext{
${ }^{77}$ Pennycook, English and the Constructs of Colonialism, 19.

${ }^{78}$ Pennycook, English and the Constructs of Colonialism, 19.

${ }^{79}$ Pennycook, English and the Constructs of Colonialism, 19.
} 
administration. Only English language made that possible considering that today, some of those constituent parts, especially, the major ethnic nationalities are not shifting grounds in the promotion of their different languages and cultures. Those who work towards the preservation of their indigenous languages can be said to be resisting colonial domination.

In most cases, within the socio-cultural framework, it is the artists and musicians who work to reduce the impact of colonization in Africa by making use of their indigenous languages in their trade. Some are conscious of this crusade while some are not. What is clear, however, is that Western culture impacted heavily on the African continent. Music and arts are heavily affected by this impact but incidentally, through music, the African has manifested their resistance against imperialism, both in the use of language, instruments and lyrics.

\section{Impact of Colonization on African Music and Culture.}

Having established political and socio-cultural hegemony in Africa, colonial ideologies and Western life styles became the ambition and desire of the colonized African. Those who acquired Western education loved to dress like Westerners, walk and talk like them, to display their superiority over their kinsmen and women. These were the new elites of the African society through whom the colonial administration controlled the economy of the land. The popular music to listen to was therefore Western music as against indigenous African music. Even in the churches, missionaries did not allow converts to use local instruments to worship, associating them with evil and idolatry. So, through colonization, Europe began to control the African mind and determine African 
taste. In this way, African culture was thereby being determined by Eurocentric lens of perceptions of reality and the standards of evaluation.

Colonization therefore introduced a new social order that negatively affected the colonized who began to perceive themselves as being inferior to Europe ${ }^{80}$ Colonial masters, who knew next to nothing, regarding the different cultures and languages of Africa, ruled Africa. As a strategy for domination and forestalling a successful revolt, they re-drew the map of Africa without the consent of Africans, and brought heterogeneous cultures and languages under one administration. The African languages were subdued from being means of communication that could overturn the colonial regime. That is why Ashcroft, Griffiths \& Tiffin argue that the English Language is a language of division instead of unity. ${ }^{81}$ One would reason that English could not have been a language of unity in a system that operated with divide and rule policy, and encouraged the study of English to understand all that is going on in the African societies. ${ }^{82}$ The aim of the colonizer was therefore to control the means of communication in the colonized societies and through the learning and speaking of English language new elites were created in the colonies.

The problem language created, therefore, was not just about language but class division and identity crisis, especially for many of the literate middle class. The folks who had learnt the colonizer's language began to see themselves as special breeds who, like Odili in Chinua Achebe's A Man of the People, 'do not care too much about our

\footnotetext{
${ }^{80}$ Ashcroft, The Post-colonial Studies Reader, 1.

${ }^{81}$ Ashcroft, The Post-colonial Studies Reader, 27.

${ }^{82}$ Ashcroft, The Empire Writes Back, 27.
} 
women's dancing,. ${ }^{83}$ 'African women's dancing represents music purely orchestrated using indigenous instruments and traditional musical pattern. Odili's statement echoes the fact that colonialism succeeded in creating new 'elites' in African society who despise their heritage, promote Western cultural values. Some of those values included musical appreciations. The new 'elites' produced by Western education desired to identify with the Europeans. However, on realising that Europeans did not accept them, they formed another society for themselves since they felt superior to the indigenes. This gave rise to a musical tradition that employed Western instruments for African musical appreciation, which is popularly known as Highlife. This term 'High-life' explains how the new 'elite' perceived their status in society.

This was how Western music began to influence African music. The instruments, rhythmic patterns, or rather, melodic patterns are influenced by Western music. Western influence also includes the introduction of nightclubs, recording studios as well as technologies, all of which were introduced to the African society during colonization. These introductions influenced music in Africa so much so that African music was no longer simply traditional music but included some adaptations of Western format. For example, musicians began to record their songs and sell them for business purposes, primarily as against the collective nature of African art. Afro-beat and bongo was no longer about African drums, gongs, flutes, xylophone, horns, rattles, and other instruments. African music now includes sounds and rhythms produced with trumpets, saxophones, guitars, keyboards and amplifiable drums. In the whole process, a hybridized form emerged - highlife, which is geared towards public entertainment overtime.

${ }^{83}$ Achebe, A Man of the People, 1. 


\section{Pre-colonial African Music and Culture}

Although the indigenous music of Africa has been influenced by so many factors such as ethnicity, cultural differences, environment, politics and the population of people who migrate from one place to another, folk songs survived and still describe the culture of a people and their community. Africans generally migrate to different places at different rates, meet different ethnic groups with their respective music and culture; they experience different climate, government, food, ways of live as well as music. The music styles of Africans anywhere they reside is influenced by their culture. Music and dance always reflect culture of a group of people and above all represent cultural production in time and place.

Most times specific instruments are chosen for specific occasions depending on one's stage in life, personality and achievements, and certain instruments are restricted to some individuals who are assigned by the leaders of the community or are cleansed by the gods. ${ }^{84}$ The community form the basis for music making which depicts their identity as a group of homesteads and villagers, and who live some kind of communal life based on common history, local traditions, believes and values. ${ }^{85}$

Music and languages are connected in African music for effective communication. In singing, composers fix the lyrics with the right tones to bring out the meaning of the song; that is to say that the tonal pattern or the text puts some constraints on the melodic patterns. Instruments like drums and gong could be perceived as texts because they are used for communication. Other examples include the wood blocks and wood drums. In a graphic description of the effect of the sound of the familiar ogene

\footnotetext{
${ }^{84}$ Bebey, African Music, 17.

${ }^{85}$ Nketia, The Music of Africa, 21.
} 
(gong) on a typical African village, Achebe asserts that the ogene rings a bell in Umuofia, when being played by the village crier of the Akakanma age group to assemble the villagers to a meeting. ${ }^{86}$. Du Bois, the father of Pan Africanism ascertains that the Negro in the Unites States used drums to send messages ${ }^{87}$ and to connect to the Africans in the continent through dance. ${ }^{88}$ Sometimes, drums are equated with man and in rare cases, to an important man in the community because of its powerful voice, which is capable of sending messages far and wide. Women are urged to respect such drums, just as they respect men. ${ }^{89}$

\section{Cross Currents: Music of Africa and the Africa Diaspora}

The European Christian religion has served as the vanguard of modernity both in Europe and in non-western societies. As the religion spreads, the indigenous religions of other places, especially those of Africa tend to decline along with the indigenous art forms. ${ }^{90}$ The early missionaries that came to the continent had the notion that drumming was associated with what seemed to the 'pagan' practice and the converts were not allowed to participate in the performance of African music ${ }^{91}$ At best, the churches made efforts to translate some of the Christian hymns to the indigenous language and the music curriculum that was taught in schools were designed with emphasis on Western music.

Thus, young Africans who enrolled in the new schools were caught up with music patterning to their new beliefs and began to see traditional music as fetish and therefore

\footnotetext{
${ }^{86}$ Achebe, Things Fall Apart, 169.

${ }^{87}$ Du Bois, The World and Africa, 123.

${ }^{88} \mathrm{Du}$ Bois, World and Africa, 155.

${ }^{89}$ Bebey, African Music: A People's Art, 14.

${ }^{90}$ Asante, African Dance, 49.

${ }^{91}$ Nketia, The Music of Africa, 15.
} 
demonic. Those who migrated to western societies like Europe and Americas were fascinated with soul music, which was one of the popular brands in United State of America in the 1940s and 1950s. Migration from villages to town and the urban life exposes the African to Western music. The need to live up to the expectations of the city life and imitation has made some Africans to turn their back on the traditional past and face the attraction towards a new life. ${ }^{92}$ As such, western music was preferred over traditional African music

African music played a significant role in the lives of the African slaves in the plantation. The original slaves from Africa had carried their inherited music tradition from home to the new world all over the world where they were sold to. Most of their songs reflected and expressed their feelings of humiliation, deprivation and desecration. They moved from one genre to another depending on their state of life. Soon after the American civil war (1861-1865) and the historic emancipation of the slaves that followed, spirituals changed from protest songs to blues. The blues was an expression of the new problems and hardships confronting the African American as a 'free' man. As a musical form, the blues has run like a spine throughout the entire history of jazz. ${ }^{93}$ Through these and or musical forms, Africans in the Diaspora contributed immensely to the development of music of the other world especially where they migrated in large numbers as a result of salve trade and commerce. The musical styles which are exchanged and diffused along trade routes made a widespread impact on black Africa. ${ }^{94}$

\footnotetext{
${ }^{92}$ Bebey, African Music: A people's Art, 140.

${ }^{93}$ Fred \& Warren, The Music of Africa, 71.

${ }^{94}$ Roberts, The Colonial Moment in Africa, 223
} 
Given the presence of Africans in the 'New World,' one can identify several similarities and difference between American and African pop music. One of the most critical disparities is that American pop music is that it is built on African rhythm and sometimes is considered to be more rhythmically interesting than the traditional African rhythm with its basics on the regular reoccurring accented beat. ${ }^{95}$ However, It has been argued by scholars like Frank Frazier that Africans in the America and their descendants have abandoned their original African music style in adaptation to that of their environment - thus, producing a new kind of folk music in that style. Presumably no other people would have accomplished this than African immigrants who through the plantation songs, spirituals, blues and ragtime have helped to launch the modern American popular music. ${ }^{96}$

\section{Recent Trends}

One of the main lessons to note is that the factors that shape and maintain musical practice in Africa are not static. They operate in the direction of both change and continuity. Although Africans were engaged in a dynamic culture of interaction across different areas and regions, the period of European colonial presence marked the evolution of new musical subcultures. ${ }^{97}$

\footnotetext{
${ }^{95}$ Fred \& Lee Warren, The Music of Africa, 70.

${ }^{96}$ Du Bois, World and Africa, 155.

${ }^{97}$ Nketia, The Music of Africa, 19.
} 
It is clear that African music goes far beyond the realm of art. Yet in these modern times, it manages to retain intact those of its former functions that have given African society throughout the ages its own particular character. ${ }^{98}$

Popular songs help us to penetrate the "mentalities" of an age, particularly traditional African mentality. Perceptions of what it "traditional" or "original" vary of course. For some it is the substratum of African Civilization, the "original reality" of Africa before it was "corrupted" by outside forces. ${ }^{99}$

African music has continued to influence the younger generation in their compositions and performances and has undergone far reaching changes. Modern music/songs are now written and performed in a style similar to that of traditional music. Some music has completely changed from what it used to be to a new style. For instance, both the highlife of West Africa and the Congo music of Central and East Africa have evolved into authentic popular music which includes the Lingala music of Zaire and the Makoosa from Cameroon. This brand of music reverberates across the African continent and the beat of a new Africa is unfolding to its tone. ${ }^{100}$ Every group is making effort to upgrade its own music to be able to perform it in an organized theatre as well as record them for the public.

The traditional music has also been much influenced by modernity and foreign cultures in a big way that electrically enabled technologies are widespread and make other forms of entertainment. For example in Nigeria there are advanced recording studios and music performers have great commercial opportunities to record and market their music. In the past, it was uncommon if not impossible to listen to recorded music

\footnotetext{
${ }^{98}$ Bebey, African Music, 142.

${ }^{99}$ Ekechi, The Future of the History of Ideas in Africa, 499.

${ }^{100}$ Asante, African Dance, 51.
} 
due to lack of the appropriate technology to store and retrieve popular and favorite songs; but life in modern society has become increasingly technical and this is having an adverse effect on African traditional music. ${ }^{101}$ The traditional and typically anonymous music that is an expression of the life of people in African community is today classified as music of the lower classes.

Recently, the term folk music has graduated and it's been described as popular music that is based on traditional music and also commercially based. Film producers and record companies aim at commercial success only and thus they have tended to emphasize popular hybridized performance which would appeal the people in the cities, rural areas and cut across nations. ${ }^{102}$

Modern music in Africa today include a variety of genres which include soul music, pop, highlife in company with blues and calypso, gospel music and jazz. The importations of western musical instrument like the keyboard, guitar, drum set, conga drum, bongo drum, string bass, trumpet, trombone, saxophone and amplifiers are increasingly becoming an African style especially in the high life music. The western dance steps are being appreciated amongst Africans today. Hymns are incorporated in vocal music especially in the Christian churches. In catholic churches, rhythmically composed songs with accompaniment replace the hymns and chants of the commons of the mass. The accompaniment includes the combination of Western and African instruments which are played by both men and women ${ }^{103}$. African music moved

\footnotetext{
${ }^{101}$ Asante, African Dance, 41.

${ }^{102}$ Bebey, African Music, 1.

${ }^{103}$ Bebey, African Music, 16.
} 
completely to a new direction and graduated into live performances for entertainment, competition and theatre to be in the same pace with the state of art in the World. ${ }^{104}$

${ }^{104}$ Bebey, African Music, 142. 


\section{CHAPTER FIVE}

\section{METHODOLOGY}

\section{Research Purpose and Specific Objectives}

The purpose of this study is to investigate how effective the bongo music is in resisting cultural hegemony through language, lyrics and instrumentation. It seeks to explore how effective the music is in communicating African philosophical reflections of life. This study examines bongo music as a medium for social commentary historically and explores how it is still practiced in contemporary times. This research addresses the following questions:

- Beyond the functions of music, how effective are the Igbo musicians in addressing socio-political and moral issues in society especially resisting cultural hegemony and promoting unity?

- To what extent could bongo music provide an insight into Igbo indigenous philosophy and way of life regarding family relations and social justice?

The focus of this research is to retrieve aspects of Igbo social commentaries in resistance to cultural hegemony, that have been reserved in songs and proverbs and that have not yet received due attention. This research specifically explores how language, musical instrument and lyrics are used as a tool to maintain cultural tradition. 


\section{Methodological approach}

To answer the questions raised concerning Bongo musicians in Igbo language speaking area, an interpretive qualitative approach is employed. Interpretative qualitative research is often used in ethnomusicology because it is a method often used to view studies such as the concept of culture and center of ethnography. The qualitative method of research aims to understand human behavior and it guides the researcher in analysing ideological perspectives underscored in the data. ${ }^{105}$ It also uses theoretical lens that form interpretations that call for actions, agendas for reform and change. ${ }^{106}$ The interpretive approach allows a form of inquiry which allows researchers to analyze what they see, hear and understand with the use of other sources. Music analysis challenges the analyst to explore systematically and describe coherently the links between the embodied experience developed in the song lyrics and the sonic and expressive elements in the music; in other words, musical analysis explores the links between the lived body and the musical practice. The interpretation of song lyrics develops an exquisite site for the reception of music and its social meanings. The analytic model used in this research is mainly the communicable aspects of musical expression; it is therefore based on the interaction of lyrical musical expression.

\section{Data Collection}

The data for this research is collected from songs found in the musical albums of the bongo musicians, autobiography of one of the musicians (Dan Orji), and previous research in form of books, journal articles and archival materials. The ten songs are

\footnotetext{
${ }^{105}$ Creswell, Research Design, 173.

${ }^{106}$ Creswell, Research Design, 189,190.
} 
chosen from different bongo musical CDs. The CDs are the musical CDs of Nze Dan Orji and Chima Eke respectively, all produced in Nigeria. The songs were selected from two different generations: Orji's songs belong to the 60 s, 70 s and 80 s while Chima Eke's songs are from the $90 \mathrm{~s}$ and $2000 \mathrm{~s}$. They include Six songs from Orji's albums; "Uba Awuu Nwa", "Ije Uwa," "Sambola Mama," "Ediquansa," "Umunnawuike," and "Meri Merimam." Chima Eke's four songs: "Akwa uwa," "Obaraeze," "Uwa nkea Sef," and "Ochu Nwambia." These were selected from two different areas so as to investigate the extent to which African music, specifically bongo music are forms of resistance to cultural hegemony through language, instruments and lyrics. These selections allows for examination of lyrics to investigation on how the music perform the same function as social commentary for resisting cultural hegemony across time.

Due to the researcher is unable to interview the artists; autobiographies are used to collect data on the background. Autobiographies are commonly used in the interpretive approach because they represent the musician's words about themselves just as they speak the writer's mind. It is widely used to represent the author's contribution in the research topic and also the finding of the study. ${ }^{107}$ The use of autobiographies is useful in the qualitative research method because it brings authenticity since it is written by the author. ${ }^{108}$ It is considered a primary document. The autobiographies are supported by selected texts.

The important groups of texts in this research are historical, African musical and theoretical materials. The historical materials provide information on the ethnography of Nigeria and the Igbo. Interpretations cannot be separated from people's own

${ }_{108}^{107}$ Jarviluoma, Gender and Qualitative Methods, 109.

${ }^{108}$ Patton. How to use Qualitative Methods in Evaluation, 7. 
backgrounds, histories, contexts and prior understanding. ${ }^{109}$ The ethnography helps to learn and understand the cultural phenomenon which reflects the knowledge and system of meanings guiding the life of the Igbo people. The historical background of the Igbo is important to understanding this study.

African music materials are used to provide the framework for the African ethnomusicology of the study. Music in Africa is an expression of life. African musicians combine sounds in a manner pleasing to the ear, expressing life through music and sound. ${ }^{110}$ This sound can only become meaningful and better understood when studied in the context of the traditional life of the African. ${ }^{11}$

The theoretical materials provide information on colonization and cultural hegemony. The theoretical lens used in this study is that of resistance to cultural hegemony Africa is a colonized continent. The concept of culture, colonization and hegemony help in providing background information on what provokes the bongo musicians to resist cultural hegemony.

\section{Data Analysis}

Data analysis in this research includes lyrical analysis and explanations on how language and instruments are used to resist cultural hegemony. The approach to lyrical analysis aims at breaking down and understanding the meaning of the songs employed in a language that enables for an effective discussion. This research presents an analytical methodology for interpretative reproduction of the material contents of the chosen bongo

\footnotetext{
${ }^{109}$ Creswell, Research Design, 176.

${ }^{110}$ Bebey, African Music, 3.

${ }^{111}$ Bebey, African Music, 4.
} 
song-lyrics. The songs texts are interpreted in order to help society to gain a better understanding and appreciation of bongo music tradition.

Text analyses of the songs are investigated and analyzed perspectives for effective social comments. The analysis involves the integration of text and textual analysis as well as literal analysis. Textual analysis in this research focuses on of the researcher's perception and understanding, and the way they make sense and impact knowledge in people's lives. The attempt is therefore to understand the multiple realities that are underscored in the lyrics of the music. ${ }^{112}$

The reason for the use of lyrical analyses is to explore communicated ideas and culture, and also bring to light and critically engage thoughts, expressions and memories in order to bring out unspoken words. Musical lyrics contain the meaning and knowledge historically and culturally situated alongside with other art forms. These art forms which include theater and paintings carry messages that are highly contextual and accessible. ${ }^{113}$ It's intellectual import and revolutionary functions, the message in the lyrics, and the symbolism of the musical instruments embody the people's philosophies. ${ }^{114}$

The bongo lyrics are analyzed into, 'decolonization,' 'unity,' 'family relations,' and 'social justice' to show how the artists through these concepts, fight cultural hegemony. It articulates the commentaries (in lyrics) of the two bongo artists, Nze Dan Orji and Chima Eke.

${ }^{112}$ Creswell, Research Design, 195.

${ }^{113}$ Knowles and. Cole, Handbook of Arts in Qualitative Research, 340.

${ }^{114}$ Oti, Highlife Music in West Africa, 45. 


\section{Limitation, Validity and Reliability}

This study is limited to two bongo musicians because of lack of time. Limited information was used on Chima Eke because not much research has been done on his music; limited time and funds hindered travelling to Nigeria for interviews and more resources.

The research is valid due to the accurate representation of the bongo musical lyrical contents. The language of the lyrics is the researcher's primary language. The content of the representation is free from irrelevant texts that threaten the validity and reliability of the study. 


\section{CHAPTER SIX}

\section{BONGO MUSICIANS}

This chapter contains the biographies of the two bongo musicians Dan Orji and Chima Eke, explicitly stating their early childhood and family life, education and work, music career and their contributions to bongo music. It further explores how they use bongo music through language, lyrics and instruments in negotiating cultural hegemony.

This chapter analyzes how Dan Orji's bongo music revolves around colonization which was the issue discussed in the 1960s at the pick of his musical career. Being a musician who lives during and after colonisation, he is able to address issues about colonization; cultural hegemony and culture resistance. Chima Eke who is a contemporary bongo musician maintains the use of Igbo language and 'bongo' drums as lead instrument, for social commentary. In this case more contemporary social issues of unity, family and social justice are explored. This chapter also explores how the negotiation of cultural hegemony is passed from generation to generation through language, instrumentation and lyrics.

\section{NZE Dan Orji: Aku Ji Eshi Obi Ike 1 of Orji (Wealth Gives Confidence)}

From my little age, I had my music calling ${ }^{115}$

Dan Orji is one of the oldest modern bongo musicians in Owerri. He is a pace setter who believes that life begins at 60 , and a well-respected leader in the Dan Orji

${ }^{115}$ Orji, The Journey so far, 6. 
community. He was born at Aro Orji Uratta in the Owerri North Local Government Area of Imo State, Nigeria on the $5^{\text {th }}$ of December 1945 into the family of the late Mazi Chima Orji.

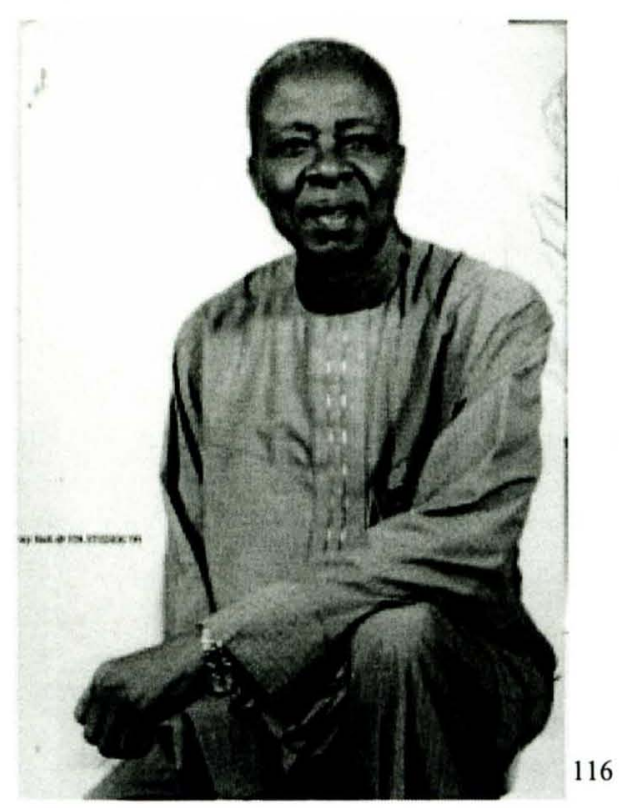

\section{Early Childhood and Family Life}

Dan Orji was born into a devout Christian (Catholic) home and was baptized. His mother was a midwife, and his father died three months after his birth in March of 1946. Dan Orji grew up in a middle class family, under the guidance if his brother, Mazi Emmanuel Amugo Chima, Emmanuel Orji who played the role of a father to him and to all the other members of his family. Dan Orji remains grateful to his elder brother whom he felt kept their father alive in their lives, for his affectionate love and care. ${ }^{117}$ Dan Orji has two wives; his marriage to the first wife, 'Ekwotosi,' took place in 1978. Later in

${ }^{116} \mathrm{http} / / /$ bongolife.com/store-2/nze-dan-orji/bongo-abiriwa/
${ }^{117}$ Orji, The Journey so far, 5 . 
1986, he married the second, 'Adaku.' He has eight children, three (Iheomagwuagwu, Chidimma, and Kelechukwu) from the first wife and five (Chinonyerem, Chikadibia, Ugochinyere, Chidiebere, and Chiebuzo) from the second wife.

Dan Orji continues to serve his family and community in many ways. $\mathrm{He}$ represents his extended family in his community meetings and had won the "Head of Family' award for three consecutive years. This award is usually given to the most resourceful elder in the Orji community. He was elected to represent his own village in the king's cabinet in 1991 and was honoured with the title 'Akujieshiobike 1 of Orji' (wealth gives confidence). He became the vice president of the King's cabinet in the same year. He also served as a vice chairman in the Orji Youth Cultural Association (OYCA) for three terms. Lastly, he has been the vice chairman of the Orji Regency Council. Dan Orji is a well-respected leader in the Orji Community because of his contributions towards the growth and development of the society.

\section{Education/Work}

Dan Orji attended St. Thomas Primary School in Owalla Uratta (a neighbouring village) and later transferred to his home school, Orji Town League School, now Orji Town Primary School, when he was grown for school. ${ }^{118}$ He proceeded to the famous St Patrick's college, ${ }^{119}$ Ikot Ansa, Calabar (SPC) for his secondary school education. For him, going all the way to Calabar (capital of Cross River State; the South southern part of Nigeria) for school was like travelling abroad. His intelligence and respect for his elders

${ }^{118}$ In his childhood days to ascertain if children had attained school age, they were asked to reach their left ears with their right hands and their right ears with their left hands, going above their heads.

${ }^{119}$ College is mostly regarded as high school in Nigeria. 
saw him through his secondary education, from beginning to end. He was well guided by his brother and uncles. ${ }^{120}$

The Biafran war broke out in 1967 while Dan Orji was still in school. All schools were closed down because of the war, and he came home from Calabar and joined the Biafran Red Cross. He got training in first aid and was posted to Awomama (a village in the Oru East Local Government of Imo State) Military Hospital as a first aid officer of the unit. At Awomama, the medical commander of the unit decided to enlist him in to the Biafran army, and he was sent for training and assigned the number 'BA192665' ${ }^{121} \mathrm{He}$ later joined nursing training for three months and graduated as an emergency nurse. He worked as an emergency nurse till the end of the war in 1970.

From childhood, Dan Orji participated actively in the village activities, like the moon light game and festivals where children and adults are educated through games, stories, music, and dance. Being close and respectful to his elders, who he referred to as his 'Igbo dictionary' 122 helped him gain a lot through oral tradition. His interactions with the elders increased his knowledge in the Igbo history proverbs and idioms which he uses in his music.

In 1976, Dan Orji joined Leemy Akakem's construction company where he worked as a public relations officer and later, purchasing officer. Leemy Akakem is his relative as well as the traditional ruler of his community. After serving the company for eight years, he left in 1984 and started his own construction company, 'Chinedu Builders', and was very successful in building houses, roads, and drainage all over

${ }^{120}$ Orji, The Journey so far, 5-6.

${ }^{121}$ Orji, The Journey so far, 7.

122 Orji, The Journey so far, 9. 
Nigeria. This company exists to date. Because music did not generate enough income, he successfully combined his music career with several business enterprises. For example: in 1985, he set up a Gregorian Restaurant at his home town, which never survived because of poor management. In 1986 he developed an interest in farming and acquired a piece of land in Osuobodo (a village in the Oguta Local Government area of Imo State) where he started a huge cassava farm and planted palm trees. He still lives in Orji today, his home town, where he manages his Construction Company and farm.

\section{Music Career}

Dan Orji started his music career in 1957 at the early age of twelve. His talent attracted the Orji Raccas Orchestra, fondly called the 'Eks' band, led by late Mr. Ekejiuba Egbulonu Njoku. Mr. Njoku got Dan Orji enrolled into the band. His mother and elder brother frowned at his inclination towards music because, for them, music was for lazy people. They wanted him to choose a 'better' profession, but later realized that he was good at what he does.

My mother and my brother were of the view that music career would ruin my life but as days went by I became a star in the whole of Owerri district. ..., in a wake-keeping at my maternal home in Owerri, my brother Mazi E. A. C. Orji, was thrilled by my melodious songs and the way I rendered them. He became convinced of my talent. ${ }^{123}$

Dan Orji did very well for himself and founded his own musical group in 1960, which he named the 'Orji Riddle Orchestra.' His band grew to be popular in Owerri and performed in many ceremonies, like weddings, wake-keepings, and burials, as well as traditional festivals and political gatherings. In 1970, After the Biafran War he started his

${ }^{123}$ Orji, The Journey so far, 6 . 
own bongo music group originally called Boy Friends' and later named 'Peacocks International Guitar Band. Dan Orji composed his first popular hit, 'Sambola Mama' in praise of his brothers and sisters, in 1958. He gained the nick name 'Danny Amadioha.' Amadioha is a name of a deity in Igbo land which means friend to all. In 1972, his single 'Sambola Mama' was released, and it became the household song of the Owerri people even beyond the 1970s. It is the number one track of his first album, 'SMASH HITS,' recorded in 1972. About one hundred and fifty thousand copies were sold in Ghana. ${ }^{124}$

'Peacocks International Band' played diverse sounds that combined genres of bongo, highlife, and traditional music. Dan Orji left the Peacocks in 1976 and formed another creative band the 'Skylarks Universal Band of Nigeria.' When the Skylarks disbanded due to migration and life became difficult. He joined a construction company and restored the Abiriwa the traditional music to his own native traditional system of bongo music. Dan Orji is considered a 'patriotic son of the soil ${ }^{125}$ who continues to revolutionize today. His other albums include Abiriwa spiritual, Bongo Abiriwa, Mbieri Special, Onusa, and the Dan Orji full Album, in which he recorded all his other music, including the songs he composed for special occasions and people.

\section{Contributions to Bongo Music of Owerri}

Dan Orji, a foremost Igbo Bongo musician who contributed much to bongo music in Owerri, revived some other Igbo music like, the Abiriwa, the Owerri version of Ekonbee - another genre of Igbo music - and Highlife. ${ }^{126}$ The Abiriwa traditional music

\footnotetext{
${ }^{124}$ Orji, The Journey so far, 7.

${ }^{125}$ An indigene of a community who is born in the land of his fathers.

${ }^{126}$ Orji, Owerri in the Twentieth Century, 171.
} 
of Owerri with which Dan Orji was involved, includes the Igba (Samba-like instrument) and agidigbo (made of planks) among other instruments. He credited himself with the introduction of the bongo into Owerri music when, in 1960, he formed his own traditional music group, the Orji Riddles Orchestra. ${ }^{127}$

Although musicians are mostly considered to live carefree lives because of the wrong notion society has about them, the importance of the African musical artist cannot be over-emphasized. Dan Orji is highly-valued by his community. He helps by raising the statues of Igbo musicians. He makes sure that musicians with him are well-taken care of each time they perform. ${ }^{128}$ The younger generation of bongo musician seek advice from him and through this way; Dan Orji is able to pass his ideologies to the younger musicians in Owerri, especially the need for culture retention.

\section{Negotiating Cultural Hegemony}

By 1945, when Dan Orji was born, there were already nationalistic movements promoting the idea of Africanism. Pan Africanists called on Africans to be proud of their heritage and to unite in order to overcome the colonial regimes. Such names like Kwame Nkrumah (Ghana), Nnamdi Azikiwe, Julius Nyerere, and Mbonu Ojike were household

${ }^{127}$ Incidentally, the surname and the name of the musician's village is the same - Orji. The name of the orchestra is refers more to the village 'Orji', which is in Uratta town. Through modernization and urbanization, Owerri, which, like Orji, is one of the villages in Uratta, became the popular name with which Uratta people and beyond are identified. Hence, Owerri is a regional name in Igbo land.

${ }^{128}$ When he takes musicians to teach their music to another community, the hosts will, on oath, promise the community of the artists concerning their safety. On arriving the host town or community, the artists go to the Eze or head of the community who allocates them to different families to take care of them. When their assignment is completed, they would take them back to their people. They were not left to find their way home because they were valuable to their community. 
names in Nigeria. They were graduates from the American and British universities who had a tremendous impact on the African societies by preaching unity and decolonization. ${ }^{129}$

With Pan-Africanism in the air, one of Dan Orji's mentors Israel Nwoba was one of the earlier musicians in Nigeria who had to join the trend. He and other artists call for unity and decolonisation. He was allegedly murdered by his band members who were predominantly Yoruba. Israel Nwoba, who is an older Igbo highlife musician, took interest in the unity of Nigeria and showed his love by having people from different ethnic groups of Nigeria in his band. He sang in different Nigerian languages, such as Igbo, Yoruba, and Hausa as well as English. One if his popular hit tracks 'Don't divide the Child' was released to advise Nigerians to be in unity. ${ }^{130}$

Even though the colonial regime had not left Nigeria in the early 1960, Africa could be said to be already in a post-colonial order. This is because: first, Ghana which is a country in Africa had already gained independence, and secondly 'post-colonial' should not be a term limited to after-independence or to mean after-colonization but a term that addresses all aspects of the colonial process, from beginning till date considering the fact that there is still indirect colonisation in most part of Africa. ${ }^{131}$ Despite independence, most colonised societies suffer indirect rule in one way or another by the by the dominant fundamental group who enjoy its position.

All post-colonial societies are still subject in one way or another to overt or subtle forms of neo-colonial domination, and independence has not solved the problem. The development of new elites within independent societies, often buttressed by neo-colonial institutions; the development of

${ }^{129}$ Obiechina, Culture, Tradition and Society in the West African Novel, 12.

${ }^{130}$ Orji, Owerri in the Twentieth Century, 166.

131 Ashcroft, The Post-Colonial Studies Reader, 2. 
internal divisions based on racial, linguistic or religious discriminations; the continuing unequal treatment of indigenous peoples in settler/invader societies - all these testify to the fact that post-colonialism is a continuing process of resistance and reconstruction. ${ }^{132}$

Nigeria being a country created out of different ethnic groups, who have different histories, cultures, languages and religions, suffers ethnic discrimination. There is no sense of unity amongst the ethnic groups brought together under one nation 'Nigeria'. This creation is an effect of colonisation. The death of Israel Nwoba, Dan Orji's mentor meant for Orji, a false sense of 'unity in Nigeria', which is the product of colonialism. Nwoba became a victim of this colonial creation.

So, in Dan Orji, we begin to see a musician with his own will and a clear vision of what he wanted to do with his music despite the cultural challenges at the time. Although English language had been entrenched and using it was considered more lucrative, he remained faithful to Igbo language. He was not scared by foreign tunes from the Beetles, Simon and Garfunkel, Jim Reeves, Don Williams and others that were becoming part of the African musical culture or the classical which the literate middle class gave attention. Moreover, having attended St Patrick's College in Calabar, Orji was linguistically equipped to take up music in English language. Yet, the Mbonu Ojike's (an Igbo Pan Africanist who also influenced Dan Orji) call for Africans to return to their traditional roots and 'boycott the boycott able' would have made its own impact on him not to abandon his root, 'his own thing'. This is the feeling Dan Orji gave when he as a baptized catholic Christian, invoked all the known pagan deities in Uratta (Owerri) in his song, Uba Awuи Nwa Mama.

${ }^{132}$ Ashcroft, The Post-Colonial Studies Reader, 2. 
Ala anyi nu ime orie biakwa gere. Ya olugba nne nwa ebere biakwa gere. Ofo ukwu biakwa gere. Nwafor nne ka ubochi biakwa gere. Amadioha ozuzu Uba nwa mama. Ota mmiri na ala Egbu biakwa gere. chei! Nne nworie biako gere, Igbudu biakwa gere, Odu eke ndi uza agba biako gere, Uzhi na aboshi Uba nwa mama. Ala bia gere, Ofo ukwu biakwa gere, Nwa afor nne ka ubochi bia koo gere, Amadioha Eziama Uba nwa mama.

(I also call on Ala, our Earth Goddess, inside Orie market place, come and hear me. Let her come along with Olugba Nne Nwaebere and listen, Ofoukwu should also come and listen, Nwafọ Nneke Ụbọchị, come and hear me, Amadioha Ozưzu, it is about Uba my sibling. Ota Mmiri in Egbu, come and listen, I earnestly implore you! Mother, Nworie, come and listen, also. Igbudu come and listen. Odueke of Uzọagba come and hear, too. Uzi and Abọshị, it is about Ụba my brother. Let the Earth Goddess come and listen; Ofọukwu, come now and listen; Nwafọ Nneke Ubọchị, come and hear me; Amadiọha of Eziama, it is about Uba my sibling. O dear, o dear... Uba my brother, o dear...)

For him, he believes that the Europeans did not abandon their own thing, so African should not abandon theirs. This belief is reflected in of some Orji's musical lyrics ideology.

This is not to say that Dan Orji did not have other influences made possible by the colonialism. Emmanuel Orji, who happens to be his elder brother, in his historical work on Owerri, indicates that Owerri musicians were more influenced by Efik an ethnic group in Nigeria and Ghanaian musicians, than by their immediate neighbours. According to Emmanuel Orji, "Gold Coast music reached Owerri through Gold Coastians who, with Efiks, Sierra Leoneans and people from West Indies were the pioneer public servants in Owerri." ${ }^{133}$ Generally speaking, Nigerian Highlife music owes much to Ghanaian musicians, especially E T. Mensah, popularly regarded as the King of Highlife music in West Africa who toured Nigeria in the 1950s. According to Graeme Ewens, Mensah's

${ }^{133}$ Orji, Owerri in the Twentieth Century, 164. 
"early popularity in Nigeria was largely uncontested, as there were few local groups playing highlife at the time and his records were well known."134 Sony Oti traces the origin of Highlife music in Ghana as accidental, resulting from segregation as the music was considered the music of the elite who live 'high life.'

It was in this disregard for highlife among the elite or western educated that moved Dan Orji's elder brother, Emmanuel, a university graduate, to persuade Dan to study music in the university, so as to fit in the 'educated high life musicians'. Dan Orji records his brother's letter to him on the day they were about to launch their highlife band, in 1970, known as the Peacocks Guitar Band with Raphael Amarabem as the bandleader.

My dear brother, I had planned that after your secondary school career you should go to university to study music and thereafter launch your own band. At the end of the war however, you refused to go back to school in spite of my urge on you to do so, after I had pointed out to you the advantages of your possessing a degree in music. Consequently, I have had no alternative than to support your idea of joining a band now although I still believe that you would make a better musician if you studied music in University. ${ }^{135}$

Dan Orji's post-Biafran war perception appears different from that of his brother who had been providing him paternal guide since their father died in March 1946, when he, Dan Orji, was still just over three months. The Biafran, being an aftermath of the colonial process and part of the post-colonial order, forced poverty on the Igbo. In his song, Ije Uwa (Life's Journey), Dan tells us that after the war, his mother consulted with him on how they were going to survive.

${ }^{134}$ Ewens, Africa O-Ye! A Celebration of African music, 86.

${ }^{135}$ Orji, The Journey So Far, 8. 
Nne m jurum ihe mga eme? Mu aza ya: A wu m oti egwu, Okwu $m$ wu egwu egwu, Aka m niile wu egwu egwu, Ochi $m$ wu egwu nu, Onu $m$ wu egwu. A ga m eti egwu.

(My mother asked who I would be and I answered: I am a musician, my legs are nothing but music, all my hands are nothing but music, my laughter is music, my mouth is music, I will play music.)

So the post-war life for him was about survival and making use of one's talent, and not necessary about going to University.

However, Dan Orji recognized that survival was not only in finding food; it also meant revival of the cultural values of his people who had been devastated by the civil war after so many years of European domination. Cultural revival filters through Dan Orji's lyrics.

It was Africa's contact with Europe through trade, even before formal colonization, that introduced the amplifiable instruments such as the guitar, the microphones, amplifier box, keyboard, and other instruments, which Dan Orji and his group were aiming to acquire to begin their new band. Aiming at acquiring those instruments meant a readiness to be part of the capitalist system introduced by colonial rule. This involves getting his music processed industrially, a system, which Ronnie Graham observes, also creates gap "between music makers and recipients." 136 He saw the need for the foreign instruments and believes that, when you live in a world, you try to take note of the changes. Music was changing and he needed the instruments to take his music to a wider audience but not to move away from his culture. He made bongo the lead instrument. Dan Orji gives an account of the instruments they were able to obtain to start off their new band.

${ }^{136}$ Graham, Guide to Contemporary African Music, 11. 
When Ralph joined me, we were handicapped for we had only Bongo and Conga sets to combine with guitar set. So there was the problem of equipment. We approached Mr. Martin Onyewuchi ...who, after listening to us agreed to bail us out. He bought a second-hand amplifier with which we took off practice. He also bought a fiddle bass as Boniface Nkwopara joined the band. With him the band was now a complete group. With Ralph on guitar, Bonny on Bass, Anii on Bongo, Young on Conga and Ejike on Maracas and my humble self as vocalist, the band took off. ${ }^{137}$

Even though the traditional instruments dominate the band, the significant thing is that his band bears the hybrid mark of colonization or what could be referred to as the postcolonial culture. It is also a mark of resistance on the part of African culture against Western culture that had the tendency to sweep it aside. The combination of instruments in bongo music can be said to be an important part of cultural negotiation and also, a true representation of the hybrid nature of the post-colonial African society. It is at the same time a form of acceptance of and resistance to foreign culture. For Dan Orji, the inclusion of Western instruments was to position him to be heard in society, for in his songs are various forms of resistance beautifully rendered.

With his comprehensive albums, just like Chinua Achebe who in Things Fall Apart, expressed and narrated the history of the Igbo people and the colonial masters in the language of the colonizer. This is very significant as a musician is able to compose and arrange his music among other kinds of anti-colonial scholarly work like Things Fall Apart. It then meant that, just as Achebe employed the colonizer's instruments of colonization - English language and the novel (narrative) - to resist the colonizer's domination, so did Dan Orji employ the Western musical instruments for the same purpose. Listening to his songs, one would say that Dan Orji is not far from the truth that

${ }^{137}$ Orji, The Journey So Far, 7-8. 
his work performed the same duties as the classic novel in the preservation of Igbo cultural values.

Traditional African music has always functioned as a community unifier, "the cement which holds society together - a hidden form of consciousness which is at once both more pervasive and more important than the overt forms of resistance to the exigencies of everyday life. In short, music constitutes the bed-rock, the grass roots of popular consciousness. ${ }^{, 138}$ In the post-colonial era, unity is an important theme, which neither the politician, the academician nor the artist could overlook because divided African societies were fundamental to the colonial success. So while politicians preached African unity, writers like Achebe advanced the Umunna wu ike (brethren is strength) ideology: "But I fear for you young people because you do not understand how strong the bond of kinship is. You do not know what it is to speak with one voice."139

With the war added to the experience of colonization in Nigeria, Dan Orji had more reasons to fear for the unity of his people. He observed in the music, Ije Uwa, that after the war, everybody went in search of what to eat; it was every man to himself. So it became significant that his first song to be recorded after the launch of their band was Sambola Mama, which he wrote in 1958. He used the names of his siblings to sing this music to underscore the importance of maintaining the spirit of brotherhood among siblings.

Sambola mama, Adaku nwanne $m$, Okechukwu nyere $m$ bu nwanneji, Ihe mmadu ka ya aka eju, nwanne, Amugo wukwanu nwanne eji m...

${ }_{138}$ Graham, Guide to Contemporary African Music, 10.

${ }^{139}$ Achebe, Things Fall Apart, 8. 
(Sambola mama Adaku my sister, God's blessing to me is my sibling, What is yours is more fulfilling, Amugo is also my own sibling...)

In his characteristic manner of playing with names, he uses the Igbo name, Okechukwu (God's portion (blessing) both as a direct name and as two words in a sentence - oke Chukwu. 'Okechukwu nyere m bu nwanne eji' - God's blessing to me is my sibling. It is a direct name because Okechukwu is one of his brothers as well as Amugo which is the elder brother's Igbo name. In the song, he criticizes those in good positions who don't care about their people with an Igbo idiom: 'Oku ngwo amaa nwanne $y a^{\prime}$ (a wine taper that does not know his siblings).

Dan Orji's other songs that addreses the issue of unity include Ediquansa and Umunna wu ike. Ediquansa is the name of his friend from the same Uratta town but another village, Umunahu.

Edquansa bia bia, Izu ka mma na nneji, bia bia.

(Ediquansa, come, It is good for siblings to consult, come).

The main body of the song contains names of well-known businessmen and public servants around Owerri metropolis which includes Mbaise district. The whole ideology is based on the Igbo brotherhood system whereby in Igbo land anyone that comes from your town or area is addressed as nwanne (my sibling) while outside Igbo land, it is extended to every Igbo person.

Bia bia bia nwanne, umu nna wuike onye ahala nwanneya e.

(Come, come, come, my sibling, brotherhood is strength, no one should abandon their sibling) 
This song promotes the philosophy of umunna wu ike which is the title of the song. In this philosophy, izu (consultation) is an important element, without which, umunna cannot function well. For umunna to function well, izu must be allowed its full circle as when the people of Umuofia in Things Fall Apart consulted before sending Okonkwo to Mbaino to bring a ransom. However, it was because $i z u$ was not allowed its full circle, which is giving every man who wanted to speak the chance to do so, before Okonkwo killed the messenger of the District Commissioner that 'things fell apart'.

Umunnawuike impacted on the Igbo society such that it was employed by James Iroha, the creator of the 1970s and 1980s most popular television drama, Masquerade (and later The New Masquerade, otherwise known as Zebrudaya the chief character in the comic series) as the sound image for the series. With the refrain of the other title, Umunna wu Ike, singing 'Bia bia bia, nwanne/ Umunna wu ike, onye aghala nwanne ya' (come, come, come, my sibling/brotherhood is strength, no one should abandon their sibling). Dan Orji's commitment to the theme of unity could not be in question. The second part of the refrain is almost a recast to a popular Igbo folk music, Uri Oma, created during the colonial era to address issues of division, identity and cultural decay.

In addressing the issue of unity, Dan Orji is also addressing the questions of language, ethnicity and identity because they are interwoven. He sang his songs in Igbo language, which could be regarded as the greatest form of resistance and restoration considering that English language was the tool the British colonizers employed to subdue their colonies. It is through language that a people can express themselves and their culture. Language gives people their own peculiar identity as Igbo, Yoruba, Ewe, Gikuyu, etc. The language of the colonizer "takes us further and further from ourselves to 
other selves, from our world to other worlds" $" 140$ and the use of African language in literature and orator is part and parcel of the anti-imperialist struggles of African peoples. Orji's resistance to colonial condition was therefore very subtle unlike the directness of musicians like Sunny Okosun, a Nigerian Musician who sang against apartheid in South Africa and colonialism in the songs, Africans Unite, Fire in Soweto and Papa's Land.

Orji's subtle approach becomes more enthralling in his song, 'Mary Merima m' (If Mary begins to subdue me), which is rightly described as one of the most beautiful attempts at lyric display in the Uratta dialect of Igbo language. "Mary Merima $m$ ' remains one of the most beautiful attempts at lyrics display in the Uratta dialect of the Igbo language." 141 This one song bears many of the characteristics of post-colonialism as it raises issues surrounding naming and identity, representation, gender, hybridity, language and religion.

Ke mma muzamara Wully, Nyiem na aza Mary, amary meriman m'awulima eee. Ariri erilanu moo ehee, A mama mu amuo muoo, muo mu nwokeoma mara mma. A papa ти атио тоo, тио тu fine boy mara mma. Nwo shi anwo g'eme mi baptism, kporom jemanu nga fada. A fada eleelam anya, fine boy mu arachi ma. Ya shi nwo we ara ya candle inahunna, we ala ya mmiri nso, oji eme mi baptism ihunna oo. Fada ajuo mama mi, oleenu ihe iga akpo nwa gi? Mama mi shi aya kporo mi Wully ooo. A wuli wulima elu oo. Mama shi aya naga aluara mi nwayi ee, luo la mi nwanyi oma mara mma, elem ukwu egbuo ewu nwanyi m ee. Kpom mu eje ama nja Misiisi $m$ eee. I swear to God mu ana hu ya anya, nwanyi amashim. Mu akporo ya lakpuo, maa ya ebirila. Anyi ebigala n'obioma nwanyi mara mma. Yaa na dunu ututu Sunday ihunna, mama mu abia duo, juma mu ihe $m$ akpo misisisim, she ya ejem akpo ya nwanyim, ya shi mkporo nini aha ya wunu Mmeri oo, eee ntom nwanne oo.

\footnotetext{
${ }^{140}$ Ngugi, 'The Language of African Literature' The Post-colonial Studies Reader, 288 290.

${ }^{141}$ Orji, Owerri in the Twentieth Century, 171.
} 
(Since I began to go by the name, Willy, and my wife answers Mary, It is now for me to be leaping for joy when Mary begins to subdue me. That's an insult for me to bear. At birth, my mother called me a beautiful boy. At birth, my father called me a fine boy, they now decided that they would baptize me and took me to the Rev Father, The Rev Father looked at me and I began to smile. He told them to bring him candle and holy water, With which he will baptise me. The Rev Father asked my mother 'what will you call your child?'My mother said, she called me Willy. Willy - to be jumping up! My mother decided to get me a wife. Got me a very beautiful woman, Astonishing beauty - with an attractive waist! A waist that fits woman's attire. I swear to God, I so loved her! And I desired her! I took her home and we lived together. We lived for one full month. Then, one Sunday, My mother came; asked me what I call my wife, I replied that I call her my wife, She said do I want the yoke to weigh me down? 'Her name is Mary!'You mean it? I am delighted, my dear!).

While telling what appears to be a love story, Dan Orji takes a critical swipe at what colonialism and Christianity brought to the Igbo society: changing people's identity through baptism, using language to confuse instead of communicating, disturbing gender relations and turning the family life upside down. The parents in this story-song have fallen in love with European names that they choose to call their son Willy and get him a wife called Mary. Willy's mother wants him to abandon the Igbo cultural practice of addressing his bride as ' $n$ wanyi $m$ ' (my wife) to calling her Mary. Similar to the attitude of European missionaries towards African culture, Willy's mother makes a caricature of the practice through misrepresentation of the second beat or syllable of the word 'nwanyi' -'nyi', which in Igbo also means 'weight'. 'Ya shi, $m$ na choro shi ihe onyi na nyi $m$ ?', which literally translates: 'She said, do I want a heavy thing to weigh me down?' In other words, for his mother, African culture is a burden, a yoke to escape from while the names Willy and Mary or Englishness represent freedom to which the post-colonial generation must fly. Surprisingly, when the mother says, Aha ya wu Mary o! (Her name is Mary) 
the man retorts: Eh? Nto m, nwanne o! (You mean it? I am delighted, my dear!) - an Igbo expression which is more often used as a sarcasm to underscore a disagreeing position.

Here language is employed to confuse and contradict instead of communicating. It is a fitting response to the colonizer whose imperial project starts with 'naming' and therefore 'knowing, ${ }^{142}$ as the basis for his control over the colonized. Not to address his woman as 'my wife' in the man's view means standing her on a pedestal from where she will not only rub shoulders with her husband, but dominate him and the man is expected to accommodate it all. For the Igbo, where marriage is patrimonial, this is cultural aberration and is insulting to the men folk and that is why the refrain ends with "That's an insult for me to bear."

Orji, therefore, fights back in his bid for cultural restoration by playing around with and misrepresenting the meanings of the new European 'Christian' names - William (Willy) and Mary, associating their sounds to Igbo words wulima (jumping) and mmeri (conquest). Mary Merima $m$ supports "much of the drama of the colonialist relations and post-colonial examination and subversion of those relations" ${ }^{\prime 143}$ which are taking place in the areas of representation and resistance. Mary Merimam is a fully hybridized text, as the title suggests with such lines as I swear to God ma ana-ahu anya which include English and Igbo. We also find words like 'fine boy', 'baptism', 'fada' (igbonized 'father') 'candle', and 'Sunday', (new introductions to the culture) fused inside the text, thereby reverting the common post-colonial trend which intermixes words from the colonized world in hybrid texts dominated by the colonizer's language.

${ }_{142}$ Ashcroft, The Post-colonial Studies Reader, 214.

${ }^{143}$ Ashcroft, The Post-colonial Studies Reader, 85. 
The body of the text represents the mindset of the African musician in the postcolonial order who refuses to be dominated by foreign culture. In addition to Mary Merima $\mathrm{m}$, Orji recorded such songs as Iwu Onye ese foto (You are a photographer), Uwa wu egwu mgbashiriko (The World is a Joke) and Eriga Gba Mgba (Eriga can Wrestle) to address the feminism of the post-colonial era. With songs such as E je $m$ Nkwo Orji (I am off to Orji Market), celebrating his village market and Nwanne o ji alu Nwanne Ya? (Can one marry their Sibling?), which celebrates the home maidens, the artist celebrates indigeneity, instils self pride in his audience, encouraging Africans to be proud of and celebrate what is theirs - their culture. Thus his first recorded song, Sambola Mama, in which he sings "What is yours is more fulfilling" (Ihe mmadu ka ya aka eju, nwanne) becomes very significant as it forms the basis for his artistic ideology. He did what could to bring back order to society because things were getting spoilt. From his music, there is no doubt that Orji played an important role in ethnic preservation in the face of aggressive westernization of Africa, especially by singing in his own indigenous language. 


\section{Chima Eke}

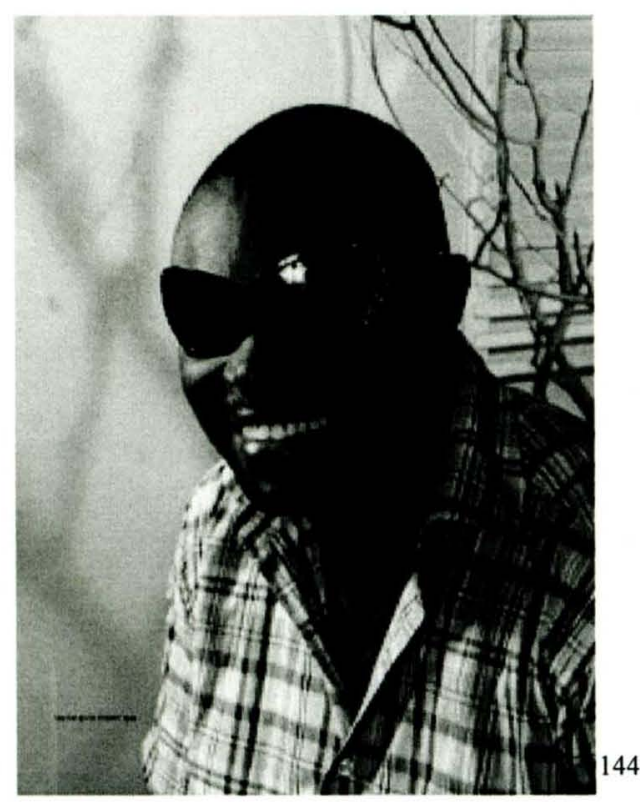

Chima Eke also known as Obaraeze (a wealthy king) was born the $4^{\text {th }}$ child of 6 on the $5^{\text {th }}$ of June, 1971. He hails from Nekede Owerri, Imo state, Nigeria. He got his primary school education at Ozorani Chiebe primary School in the Enugu State of Nigeria. He received his secondary school education at his home, town Nekede Secondary School. Although he was intelligent, he did not have the opportunity to further his education to the university level because of funding. He transferred his intelligence to his apprenticeship as a painter and electrician. Eke is currently married to Mrs. Confidence Eke with three children, two girls and a boy.

Chima Eke or 'Nwa Egwu' (child of music) as he refers to himself, is naturally gifted. He started singing in the church and later joined the village band 'Generation

${ }^{144} \mathrm{http} / / /$ bongolife.com/chimaeke/ 
Band,' which was formed by an older bongo musician, Dr. Sir. Foreigner, also known as 'Eze Bongo' (the king of Bongo). The Generation Band was made up of musicians who, today, are all bongo musicians. They were Foreigner, Eluigwe Nwa Ugorji, Umu Ejima (twins) and Chima Eke. Chima Eke first started with playing on konga drum, and then he was a back up vocalist and later started his own band in 2000 with the name 'Obaraeze Chima Eke'. One of his setbacks at the beginning of his new band was that he lost his father and mother in 2000 and 2002, respectively. Shortly after their deaths, he started his own band. His debut album, titled 'Obaraeze' with the hit track 'Akwa Uwa' (cries of the world) was released in 2003. The album sold millions of copies all over Nigeria. Akwa uwa was dedicated to his mother, and it puts tears in the eyes of his fans. Eke released his second album titled 'Uwa nkea self' (What a World) ${ }^{145}$ in 2004.

His other albums include 'Ezi Aha ka Ego' (good name is better than wealth) released in 2006. 'Odima' (Let it be) in 2007 and 'Ejike Eme Uwa' (Take things easy in the world) in 2009. Eke loves music and he appreciates his fans. He also mentors and encourages the younger generation to pursue their individual talents and passions. He is most grateful to Foreigner, the founder of the Generation Band who he refers to as his mentor, someone that gave him an opportunity to express his talent.

\section{Negotiating Cultural Hegemony}

Chima Eke being a contemporary bongo musician is influenced by Dan Orji's ideology. His songs are composed and performed in the Igbo language. He throws in

${ }^{145}$ A phrase in Igbo language used to express how one views the World. He states that no one has everything in the World and that the World is a stage where human beings act and give way for others, and then proceed to answer questions about the kind of life one lived. 
English words sometimes in sarcasm. The Igbo language which is a tonal language allows him the use of expressions in form of ululations, idioms, proverbs and parables which are better expressed in the indigenous language.

Chima Eke instruments include a mixture of traditional and Western instrument. Group of bongo drums constitute the larger part of the instrumentation and they are the most important instrument in Chima Eke's instrumental ensemble. He uses modern amplifiable instrument for larger audience and for the theatrical performances.

Chima Eke's lyrical content deals with the happenings of the day to the life, especially family relations as well as social justice. He uses his music in conversing cultural hegemony. Living a communal life is an essential part of Igbo culture. He stresses the need for the Igbo people to maintain the culture of looking out for others instead of the individualistic culture of the Western world. ${ }^{146}$

Chima Eke's songs deal with human relationships both within the family and in the wider society. In the song, Akwa Uwa, Chima expresses the emotional tie, which exists between a mother and her son. He recorded this song in honor of his mother who passed.

Akwa Uwa, Uwa shiri ike, akwa uwa wu ihe nwa eji ebela Nne ya, mgbe uwa ramara ya, akwa uwa wu ihe onye eji ebere chi ya. O ri nwa jikwaga ibe ya akwa?

\footnotetext{
${ }^{146}$ When I arrived the USA in July 2010, I heard a roommate who was very friendly when we moved in. We ate together, went for shopping together and told stories about our two different 'worlds' (Africa and America) and culture. At the end of August, she 'disappeared into thin air' with her phone switch off, and she was not coming up on facebook as usual. I became worried and did not know what to do. After one week, she came online on facebook and I wrote: "Oh dear (name), I have been worried about you, and she replied: "Just mind your business." I told my classmates the story and they said: "...well...that is America for you."
} 
(world lamentation, the World is difficult. lamentations about life is what a person directs to their personal god and mother when the world becomes difficult. Can a child dress up another child?)

He uses it as an avenue to make the point that a mother is invaluable for as he says in the song, 'akwa uwa wu the nwa eji ebela Nne ya, mgbe uwa ramara ya' (A child's life lamentation is always directed to their mother when life becomes very difficult). Within this statement is an underlying belief among the Igbo regarding the supremacy of the mother. This worldview is encapsulated in the Igbo name 'Nneka', which literally means 'mother is greater. 'In Things Fall Apart, Chinua Achebe explains the implications of this name when the principal character of the novel, Okonkwo went into exile to his maternal home and was feeling depressed. His maternal uncle Uchendu therefore made this clearer when he said: "It is true that a child belongs to its father, but when a father scolds his child, it seeks sympathy in its mother's hut. A man belongs to his fatherland when things are good and life is sweet. But when there is sorrow and bitterness, he finds refuge in his motherland."147

It is the Igbo conviction that mother is irreplaceable that the Igbo have the saying: 'Onwu nne siri ike' (the death of a mother is hard to bear). Understanding how the Igbo regard motherhood will help one to appreciate Chima Eke's lamentation song in memory of his mother. Ideologically, Chima Eke seems to depart from a more popular concept of 'akwa $u w a$ ' in the Igbo society. For the Igbo 'akwa uwa', (literal translation: world lamentation) which means lamentation over the vicissitudes of life, is said to be what people direct to their personal gods in search of succor. That is why in the mid-1970s, the Oriental Brothers, which took bongo music to a higher level, also had a song titled $A k w a$

${ }^{147}$ Achebe, Things Fall Apart, 116. 
$u w a$. In that song, they underscored the Igbo ideology that one's personal god is there to listen to one's lamentations and complaints of how badly this world is treating them.

According to the Oriental Brothers, 'akwa uwa wu ihe onye eji ebere chi ya' (lamentations about life is what a person directs to their personal gods). It is important here to observe that in Igbo traditional religion people are believed to have personal gods, chi, assigned to them by the Great God, Chukwu. These personal gods act as mediators between humans and Chukwu, the Supreme Being. This puts them in the position to solicit on behalf of human beings and that is why human beings take their prayers to them for onward presentation to the Supreme Deity. This means that replacing chi (personal deity) with nne (mother) as the receiver of one's lamentation or prayer, Eke appears to raise the status of mother to that of a god (goddess) mediating for her children before the Supreme Being. This could be said to be so within the post-colonial Igbo society where Christianity has replaced traditional religion. However, the Igbo concept of personal gods remains strong and that is why to this day, the Igbo would refer to a person who experiences misfortune regularly as onye nwere chi ojoo (one who has a wicked 'personal' god).

Far from replacing chi with nne, Eke still recognizes the Igbo ideology when later in the music he sang "e beela $m$ akwa uwa begara chi m" (I have cried about life unto my God). This lamentation - crying unto his personal god - one can argue is in relation to the emotional pains he is experiencing due to the loss of the mother. By proclaiming that a child cries unto the mother and looks up to her in difficult situations, Eke is therefore not contradicting Igbo worldview but is hereby contributing to it. The contribution he is 
making here is that calling everyone's attention to the fact that parents, especially mothers, play godly roles in the lives of their children.

It is in this way that he uses his music to encourage good relationships among families, especially, affection and respect for mothers. The loss of a mother, creates a big vacuum and does not help the children to have good sense of direction, hence the idiom "O ri nwa jikwaga ibe ya akwa?" (can a child dress up another child?). Mothers are needed to dress up the children; in other words, they are the primary educators for their children and this is the case in Igbo land.

Eke also uses this title to re-enact Igbo communal practice of condoling with one another when he calls out to his friends and supporters, announcing that the mother has departed. In Igbo traditional society, death brings friends, relations and admirers together to mourn the dead and support the bereaved emotionally and financially to deal with the crisis.

More prominent in Eke's music collection is his commentary on social justice. $\mathrm{He}$ has a number of titles including Obaraeze, Ochu Nwambi, Uwa nkea Sef and Oche sha ya me gam, through which he speaks against oppression of the poor and preaches social justice in society. In his first album titled Obaraeze, he uses the track titled Obaraeze to give the full length of what appears to be one of his given names. - Obaraezeegbulam (let him that has grown wealthy spare my life).

Obaraeze gi egbukwala $m$ o mu anoro kpa $m$ ha. A Chukwu kere onye eze, Ya kere nwambi. A Chukwu kere onye bara eze n'elu uwa kara mo. Mgbe anyi ruru n'ihu Chukwu, Anyi niile na ha otu n'ezie, n'ezie.

(You that have grown wealthy, please spare my life. Let me be - at my level. It is God that created the rich, He created the orphan. It is 
God that created the wealthy above me. When we arrive before God, We shall all become equal).

In this song, he goes on to educate and warn those who employ their wealth to oppress the poor that life has got another dimension - the spiritual - where everyone is equally regarded.

In most of his songs where he comments on social inequality and oppression of the poor and orphan, Eke makes reference to God in order to appeal to the conscience of the oppressors. In the track, Uwa nke a Sef (This kind of world) he reminds us that no one is complete with everything and therefore addresses the oppressors who usurp what belongs to the poor that God's instruction is for them to release to the poor what belongs to them.

Otu ubochi onye owula ga-aga n'eligwe, Jee zaa maka udi ndu o biga n'uwa. Eshi ahu ome njo ga-ahu njo ya anya, Ome mma gaahu mma ya.

(One day, everyone will go up to answer for the kind of life he has been living. That day, the sinner will see all their sins; the righteous will see all their good deeds).

Eke constantly makes use of an Igbo idiom, 'Onye ji ihe nwata welie aka ya elu, aka rama ya ahu ya eweda ya.' (He that holds up what belongs to a little child will bring it down when his hands begin to pain him).

Coming from a poor background, one can appreciate Eke's obsession with social justice, especially within the period, when many people had acquired wealth through foul means and took interest in depriving others of their rights and inheritance. By the mid1990s, Owerri had become a haven for gangsters, a safe abode for the international criminal gang popularly known as OBT or 419 . OBT is the acronym for Obtaining by Trick against which the Nigerian military regime of Ibrahim Babangida promulgated a 
decree known as Decree 419. Unfortunately, instead of being deterred by the decree, which made the offence of obtaining by trick punishable, it rather boosted the criminals and their activities. Their activities included ritual murder, dispossessing people of their property, especially land, armed robbery and deliberate obstruction of traffic and scam at home and abroad. To douse the tension in society, their propaganda was that they were making money by cheating their European and American acquaintances in order to retrieve some of Africa's 'stolen wealth'. This divided the people's opinion regarding their wealth. While some criticized them and indeed considered them abhorring, others hailed them as heroes who had arisen to retrieve their wealth lost to the West through colonialism. Many were oblivious of the fact that these were responsible for the unresolved murders, deaths and missing persons. It was only when it became clear that these were responsible for the atrocities in society, such as ritual murder and kidnapping that the people rose against them leading to the destruction of properties known to belong to them in 1996.

However, despite the people's response in September 1996, these criminals had established themselves in the government of the land and had developed a culture of 'might is right', of bullying others and oppressing the less privileged. There is every reason to believe that Eke, who was already in his twenties during the rise of 419 and a native of Nekede, Owerri, had been affected by the activities of these criminals because their activities could be said to have affected every individual living in and around Owerri. For example, on the walls and door frames of many houses in Owerri during that period, there was the inscription 'THIS HOUSE IS NOT FOR SALE' to serve as deterrent to these men who forced landlords to sell their houses and eject their tenants 
without adequate notice. In other words, everyone living in Owerri was psychologically affected by what was going on because no one knew whose house was their next target or the next person targeted for ritual murder. Describing the situation then in Owerri in his poem, 'Smoke in a White City', Chikwendu Anyanwu wrote: "We waded through the city as through troubled waters" and went on to compare the trauma of the period to that of South Africans during the apartheid regime:

Our nights - fierce like Mtshali's

Nightfall in Soweto:

His could be strange hands lurking

In darkness, but ours - brother's hands

Clipped and clipped like shears. ${ }^{148}$

The situation was made worse by their gaining government protection such that most of them had policemen and government security agents assigned to them. In this case, they were afraid of no one. This is why Eke's songs, which thematically address the oppressive society, are constantly evoking the sense of God hoping that the perpetrators of evil fear God. In the song, Uwa Nke a Sef, Eke speaks of death and judgement before God as part of his crusade against oppression.

In evoking the sense of God, Eke develops a resistance mentality against oppression. This is what one who understands Igbo language and its motive feels with the expression ' $O$ che sha ya mega $m$ ?' (Does he think he is dealing with me?), which is the title of one of his songs. 'Dealing' here in the Igbo context is best interpreted as 'maltreating'. ' $O$ che sha ya mega $m$ ?' is an Igbo phrase and a rhetorical question that carries within it the implicit answer 'owu (owughi) $m$ ka o mega: onwe ya ka o mega.' (I am not the one he is maltreating: he is maltreating himself). This answer is made based

${ }^{148}$ Anyanwu, I Dance Ala-Igbo, 41. 
on Igbo religious belief that Eke suggests in this song that one dealing with the helpless and the orphan is at war with his maker. This is probably why he warns the oppressor in the song, Ochu Nwambi (Pursuer (Oppressor) of the Orphan) that the orphan could one day become a king.

Churu nwambi, churu nwambi chii n'ohia! I chubagara ya ndi iro ya shi now (ha) gbuo. I makwarala shi mgbe na mgbe owula, $\mathrm{Na}$ nwambi nwere ike iwu onye Eze?

(Chasing and chasing the orphan into the bush, You pursue him into the hands of his enemies to kill him. Do you realize that at any moment in time, an orphan could become a King?

The rich and the orphan are constant features in Eke's music. This is no surprise considering that by the time he released his first album, Obaraeze, he had lost both parents, making him an orphan. In the lyrics above, one can argue that Eke is making reference to himself, who though began professional music as an orphan has become one the most successful new generation musicians. His is an example of the story of 'from grass to grace.' From being a poor orphan to becoming a rich king may appear a dreamer's vision but in Igbo land, it is not. Basically, Igbo society is egalitarian, where kingship is not inherited. The society used to be described in pre-colonial times as "Government without Kings" 149 because as the saying goes among the Igbo "there is a king in every man'. This makes it possible for a poor orphan who works hard and is popular in a community to become their king. There is every reason, therefore, to believe that Eke's songs emanate from his personal life experiences and that it is his peculiar circumstance that has made him a good ambassador for social justice. With the idiom,

${ }^{149}$ Davidson, West Africa before Colonial Era, 127. 
'he who holds up what belongs to a little child...' appearing in many of his tracks, even in the Akwa Uwa song, there is a sense in which Eke believes that time and providence will always play their role in the administration of social justice.

Considering the onslaughts on African culture from the colonial regime and the Christian missionaries, the survival of African music testifies that it is a reliable art form for the expression and preservation of African cultural values and ideologies. Singing in Igbo then, one would have thought that Orji and Eke would not stand the test of time but they have. Their fans around the world today on the You-Tube post many of his tracks and commendable comments. It is to his credit that some of the new generation Igbo bongo musicians launch themselves into the trade by copyrighting Orji's songs, though without permissions. His decision not to take legal action against such musicians could be considered a testimony that even today the African artist still believes arts belong to community. In this way, African music has taken the lead in directing how Africans in all walks of life should approach the post-colonial order - adapting the good from other cultures to improve society but to not to allow such adaptations to dictate our relationship with our fellow Africans. This is because the post-colonial order demands that Africans must be united for the preservation of the African race. 


\section{CHAPTER SEVEN}

\section{CONCLUSION}

This study supports the thesis that art in Africa has always been used as media of communication between artists and society. Arts provide effective means for social commentary. For example sculpture making, as in the case of the Mbari (image gallery) system found in the Igbo language speaking area in the pre-colonial times, were used to comment on issues. Artists from every generation make new Mbari to represent the world as they see it and offer the images to the god of the land or to Chukwu, the supreme deity. This implies that art is not just a tool for social commentary but can also be offered as sacrifice to please the god. ${ }^{150}$

African music is arguably, the most accessible and effective medium for social commentary among artistic forms. It is one art form which people can take with them to other activities such as, farming, office work, home chores and driving as well as in leisure times; because of its accessibility in modern times through technology. Although the indigenous music of Africa has been influenced by so many factors such as colonization, ethnicity, cultural exchange, environment, politics and migration, the lyrics of songs still describe the culture of the people, and everything happening in society. African song texts embody culture and above all state and represent issues at hand and

\footnotetext{
${ }^{150}$ Metuh, E I, African Religions in Western Conceptual Schemes: The Problem of Interpretation $\left(2^{\text {nd }} \mathrm{Ed}\right)$, Jos, Imico Press, 1991
} 
the feelings of the people. Some rules govern choice of songs to sing and specific occasions to perform the songs depending on one's stage in life, personality and achievements.

Among some ethnic groups in Africa, one has to belong to a certain group or perform certain rituals before being able to do certain songs or participate in some traditional ceremonies. ${ }^{151}$ The musical lyrics of groups influence and at the same time represent their cultural and social issues. There is no gainsaying that in Africa, music speaks to the people and effectively, too, especially when the indigenous languages are employed.

African indigenous languages are filled with imageries and figurative speech, which take the audience to a deeper reflection for the meaning to appear ${ }^{152}$. In singing, composers fix the lyrics with the right tones to bring out the meaning of the song; that is to say that the text puts some constraints on the melodic patterns. This is why musicians singing in the Igbo language make sure they use the appropriate tonality for the words. Igbo language is replete with words that share the same spelling but with different meanings. Tones create the meanings and this is important for the musician who hopes to communicate effectively to society.

In communicating to society, lyrics and instruments like the drums, talking drums, the gongs, the wood blocks and wood drums communicate to the people in a language they understand. In a graphic description of the effect of the sound of the familiar ogene on a typical African village, Achebe notes that "the silence was broken by the village

\footnotetext{
${ }^{151}$ Bebey, African Music: A people's Art, 17.

${ }^{152}$ Emenyonu, E N, The Rise of the Igbo Novel (Ibadan, Oxford University Press, 1978) 6.
} 
crier beating his sonorous ogene. He called every man in Umuofia, from the Akakanma age group upwards, to a meeting in the market place after the morning meal. The 'drums' are held in high esteem and respected in most regions. ${ }^{153}$ The African slaves maintained this tradition in the plantation. ${ }^{154}$ "The development of the drum language by intricate rhythms enabled the natives not only to lead in dance and ceremony, but to telegraph all over the continent with a swiftness and precision hardly rivaled by the electric telegraph" ${ }^{\prime 55}$. In certain circumstances, the drum is considered as important as a wellrespected man in society, with a powerful gift of oratory. ${ }^{156}$

In Bongo, the drums are at the center of the music. One can actually say, without the drums, there is no bongo. Bongo music is an offshoot of older Igbo music example the 'Abiriwa' traditional. In Igbo cultural context, the word bongo and drums are synonymous. With the drums performing at the centre of Bongo music, people naturally think of this highlife genre as only for dance and hip wiggling for which Owerri is known. Bongo music is not all about dance as exemplified in the works of Dan Orji and Chima Eke. There is no doubt that there are some misinformed bongo artists who see it just for the entertaining dance it brings to the arena and nothing more. Often such artists (if at all they deserve such qualification) only sing banality.

However, Bongo music has, since its foundation, been graced by intelligent and committed artists who are believed to be gifted in music. Such individuals and groups apart from Dan Orji and Chima Eke include the likes of Oriental Brothers, Ederi Olariche, Joseph Oguchialu Jacobs also known as Sarowiwa, Stanley Nnorom, Ebere

${ }^{153}$ Achebe, Things Fall Apart, 169.

${ }^{154}$ Du Bois, The World and Africa 123.

${ }^{155} \mathrm{Du}$ Bois, World and Africa, 155.

${ }^{156}$ Bebey, African Music: A People's Art, 14. 
Obiako, Sir Warrior and his Oriental brothers, etc. Oriental Brothers, a group of the 1970s, for instance, were known to address issues of the moment in society and go into the studio with them. This is true of the song titled Osa enwe (ghi) akwu, based on a factual incident where two men engaged in a dispute over a land that did not belong to any of them.

In other words, one can confidently respond in the affirmative to the question whether bongo music can provide a veritable and effective medium for social commentary which is used to resist cultural hegemony. Ranging from family to sociopolitical and moral issues, bongo musicians have always felt a responsibility to address them. Such is the music of Dan Orji and the music of Chima Eke, whose songs are transmitting one message or the other to society. Akwa Uwa by Chima Eke exposes the filial love between mother and child even at death and the quest for social justice. There is a call for social justice in the song that cries about the deceased mum because often uncles and neighbors tend to maltreat orphans. As pointed out in Chapter six, the polarity between the rich and the orphan featured so much in Chima Eke's songs. Dan Orji who started bongo during the colonial period reveals the effects of colonization and the need for decolonization and African unity.

As social commentators, their songs provide an exciting gateway into Igbo philosophy and way of life. This is the effect of their use of idioms and proverbs. For instance, many of Eke's tracks as pointed out earlier contain the proverb, onye ji ihe nwata welie aka elu, aka rawa ya ahu ya eweda ya. (He that holds up what belongs to a little child will bring it down when his hands begin to pain him). This proverb helps us to understand that the Igbo believe that no oppression lasts and therefore advocates for 
patience. The use of proverbs and idioms in music help the audience to acknowledge the seriousness of the musician as a social commentator. Dan Orji's first hit track in the early 1970s, Sambola Mama, created a social idiom for the Igbo with the phrase okungwo ama (ghi) nwanne ya (literally: a wine tapper who does not recognize his sibling), meaning one in a good position but does nothing to help people around them. So, Bongo highlife musicians not only comment with already existing idioms, (sometimes to create new ideologies and sometimes to sustain older ideologies), they also create and initiate new sayings and build social ideologies.

For future research, the musical practices of women in the Igbo language speaking are recommended. Some bongo musicians including Dan Orji address the issue of gender relations and the effect of feminism in the pre-colonial Africa. The study of women musical practices is crucial for a better understanding of how Igbo women fare in the Igbo society and Africa. 


\section{REFERENCES}

Achebe, Chinua. Echi Di Ime: Taa Bu Gboo (Odenigbo Lecture). Owerri: Assumpta press, 1999.

- The Igbo World and Its Art" in Morning yet on Creation Day. New York: Anchor Books, 1976.

- A Man of the People. Oxford: Heinemann Educational Publishers, 1966.

—. Things Fall Apart. Oxford: Heinemann Educational Publishers, 1958.

Agbasiere, Joseph-Therese. Women in Igbo Life and Thought. New York: Routlegde, 2000.

Anyanwu, Chikwendu. I Dance Ala-Igbo. London: Lumen Veritas, 2000.

Asante, Kariamu Welsh. African Dance: An Artistic, Historical, and Philosophical Inquiry. Africa World Press, Inc, 1998.

Ashcroft, Bill, Griffiths, Gareth and Helen, Tiffin. The post-colonial studies reader London: Routledge, 1995.

Basden, George Thomas. Among the Ibos of Nigeria. London: Frank Cass \& Co. Limited, 1966.

-Niger Ibos. New York: Barnes and Norble, 1966.

Bebey, Francis. African Music : A People's Art. London: Harrap, 1975.

Cowell, F. Culture in Public and Private Life. New York, Praeger, 1959.

Crowder, Michael. The Story of Ngeria. London, Faber and Faber, 1962. 
Creswell, John. Research Design: Qualitative, Quantitative and Mixed Method Approaches. Los Angelis:Sage, 2009.

Du Bois, William. The World and Africa: An Inquiry intothe Part which Africa has Played in World History. New York: International Publishers, 1965.

Eliot, Thomas Stearns. Christianity and culture: The idea of christain societies and note towards the definition of Culture. New York: Hacourt Brace, 1949.

Ekechi, Felix. Tradition and Transformation in Eastern Nigeria: A Sociopolitical History of Owerri and Its Hinterland. 1902-1947. Ohio: The Kent state University Press, 1989.

_ "The Future of the Histories of Ideas in Africa," African Studies Review 30, no. 2. 1987.

Emenyeonu, Ernest. The Rise of the Igbo Novel. Ibadan, Nigeria ; New York Oxford University Press, 1978.

Easthope, A. and McGowan K. A Critical and Cultural Theory Reader. Buckingham, 1992.

Ewens, Graeme. Africa O-Ye! : A Celebration of African Music. A Da Capo Paperback. New York, N.Y., USA: Da Capo Press, 1992.

Falola, Toyin. Culture aand Customs of Nigeria. Westport, Conn.: Greenwood Press, 2001.

The history of Nigeria. Westport, Conn.: Greenwood Press, 1999.

Forde, Daryll and Jones, G. The Igbo and Ibibo-Speaking Peoples of South-Estern Nigeria. London: International African Institute, 1950. 
Graham, Ronnie. The Da Capo Guide to Contemporary African Music. New York: Da Capo Press, 1988.

Ifionu, Azubuike. "The Role of Music in Igbo Culture: An Ethnomusicological Explanation." Igbo Language and Culture 2 (1982).

Jacobs, Joseph Oguchialu. Bongo jere Uzo Ije: Sarowiwa Apalila Egwu. 2005.

Jarvilioma, Helmi. Gender and Qualitative methods. London; Thousand Oaks, Calif.: SAGE, 2003.

Knowles, Gary and Cole, Ardra. Handbook of the Arts in Qualitative research: Perspectives, Methodologies, Examples and Issues._Los Angeles: Sage Publications, 2008.

Kroeber, A. and Kluckhohn, Clyde. Culture: A critical review of concepts and definitions. Cambridge, Mass., The Museum, 1952.

Loomba, Ania. Colonialism-Postcolonialism 2nd Ed (the New Critical Idiom). London ; New York: Routledge, 2005.

Mazrui, Ali Al'Amin. The African Condition: A Political Diagnosis. London: Cambridge University Pree, 1980.

Ngugu, Wa Thiongo. Decolonising the Mind: The Politics of language in African Literature. Oxford: James Currey, 1986.

National Archives of Nigeria Enugu, AWDIST 2/1/56 Dances harmful or otherwise report on, 1919.

Njoku, Raphael. African Cultural Values: Igbo Political Leadership in Colonial Nigeria, 1900-1966. New York: Routledge, 2006.

Nketia, Kwabena. The Music of Africa. New York, W.W Norton, 1974. 
Orji, Dan. The Journey So Far (an Autobiography). Owerri: Otis Computers, 2005.

Orji, Emmanuel. Owerre in the Twentieth Century (1901-1999). Owerri: Casers Limited, 1999.

Oti, Sonny. Highlife Music in West Africa. Lagos: Malthouse Press, 2009.

Patton, Michael Quinn. How to Use Qualitative Methods in Evaluation. Newbury Park, Calif.: Sage Publications, 1987.

Pennycook, Alastair. English and the Discourses of Colonialism. London/New York: Routlegde, 1988.

Roberts, Andrew. The Colonial moment in Africa. Cambridge University Press, 1986.

Salloum, Trevor. The Bongo Book.

Warren Fred and Lee. The Music of Africa: An introduction. Englewood, N.J., Pretice Hall, 1970.

ONLINE SOURCES

http://commons.wikimedia.org/wiki/File:Un-nigeria.png

http://www.onlinenigeria.com/mapethnic.asp

http://bongolife.com/store-2/nze-dan-orii/bongo-abiriwa/

http://bongolife.com/chimaeke/ 


\section{CURRICULUM VITAE}

Department of Pan African Studies

University of Louisville

Phone: 502-381-0365

Louisville, KY 40229

\section{RUTH STELLAMARIS OPARA}

rsopar01@,louisville.edu

\section{PERSONAL DATA}

Date of Birth: July 20, 1980

Languages: $\quad$ Igbo, English and West African Pidgin.

Country of Origin Nigeria

Sex/Marital Status Female/Single

\section{EDUCATION}

MA. Pan African Studies. University of Louisville, Kentucky, USA.

- Thesis: "Art as a Media for Social Commentary: A Case Study of Igbo Bongo Musicians, South-Eastern Nigeria".

Graduate Teaching Academy. University of Louisville, Kentucky, USA. 2011

- Scholarship of Teaching and Learning in Higher Education

BA/BED. Music Education (second class honours upper division). University of Nigeria, Nsukka, 2007. 
- Thesis: Problems and Prospects of Teaching Music in Primary Schools in Nigeria

National Teachers Institute (NTI), Nigeria, 2000.

- Principle and Practice of Education

\section{PUBLICATIONS}

\section{REFERRED JOURNAL ARTICLES}

1) "The Influence of Igbo Traditional Music on Modern Igbo Music," Notes and Records: An International Journal of African and African Diaspora Studies 1, no. 1(2011): 5770 .

2) "Music Education and Creative Society: The Role of Music Teachers," AJOMAH: Alvan Journal of Music and Humanities 1, no. III (2009): 69-73.

\section{ACADEMIC CONFERENCES/PRESENTATIONS}

2011 University of Louisville Saturday Academy, Louisville, Kentucky. "Prospective on Africa."

2011 AFTA 2011 International Conference (Swansea Metropolitan University, Wales UK) "Towards Decolonization: The Effect of Hybridity in Igbo Highlife Music."

2011 The $12^{\text {th }}$ Southern Interdisciplinary Roundtable on African Studies (SIRAS) Frankfort Kentucky, "The Influence of Igbo Traditional Music on Modern Igbo Music."

2011 National Council for Black Studies $35^{\text {th }}$ Annual Conference (NCBS) Cincinnati, Ohio, "Blues People: Music and the African Cultural Heritage."

$20091^{\text {st }}$ National Conference on Music, Education and National Development, Owerri, Nigeria, "Music Education and Creative Society: The Role of Music Teachers." 


\section{PRIZES/AWARDS/HONORS/FELLOWSHIPS/SEMINARS/WORKSHOPS}

- Graduate Assistant Award, Department of pan African Studies, University of Louisville, KY, USA 2010 till date. $\$ 20,168$ annually.

- International Center Travel Grant to Wales, University of Louisville, 2011 $\$ 400$.

- Graduate Teaching Academy, AFTA Conference Grant, University of Louisville 2011. $\$ 150$.

- Department of Pan African Studies, AFTA Conference Grant, University of Louisville. $2011 \$ 150$.

- Graduate Student Union, AFTA Conference Grant, University of Louisville 2011. $\$ 100$.

- Department of Pan African Studies, SIRAS Conference Grant, University of Louisville. 2011, $\$ 95$.

- Certificate of Completion for attending the requisite number of Plan Workshops, School of Interdisciplinary and Graduate Studies, University of Louisville, 2011.

- Undergraduate Student Full Scholarship Award, Catholic Archdiocese of Owerri. 2003-2007. Tuition for four Academic years.

- Pine Wood Hotel Singing Competition. 2000. N3,000

- Certificate of Completion, Competency Test in Preventing Sexual Harassment, University of Louisville, 2011.

\section{TEACHING/WORK EXPERIENCE}

\section{Taught Courses}

Teaching Assistant University of Louisville, Louisville, Kentucky. USA (2010-2011)

- African Music/History

- Slavery in Nigeria

- Music and Religion in Africa 
- African Music History

- African Dance

- African Music Ensemble

- Primary Voice

- Primary Violin

- Rudiments of Music

- Primary Ear Training

- Music Education

Regina Pacis College, Abuja Nigeria (2008-2009)

- Music Teacher

- Choir Mistress

Strauss School of Music and Dance Abuja, Nigeria (2007-2008)

- African Music and Dance

- Rudiments of Music

- Primary Voice

- Primary Violin

\section{ADMINISTRATIVE POSITIONS}

2007 Production Secretary, to "Kingdom of the Mask". A stage adaptation if Chinua Achebe's "A man of the people" by Chikwendu Anyanwu.

2006-2007 Vice President, Student Union Government (SUG)

2001-2006 Secretary, Whelan Research Academy, Pastoral Centre Owerri, Imo State, Nigeria.

2005-2006 Student's Judge, Student's union Government

\section{PERFORMANCES}

2011

A Night of Songs and Poetry featuring Ruth Opara. Organized by Igbo Language Conference, London. 
Yetunde and Chorus, in "How Orisanmi Chose his Head." A play written and directed by Nefertiti Burton, Professor of Theatre Arts, University of Louisville, Kentucky.

2008-2009 National Youth Service, Nigeria.

2001-2003 President, St Michaels's Parish choir

2003-2005 Choir Mistress, St Michaels’s Parish choir

2004 Treasurer, Music Students Association of Nigeria, AIFCE Chapter

I have performed (singing and dancing) in concerts, churches, Nigerian Independence Ceremonies, Odenigbo Festivals

\section{COUNTRIES VISITED/LIVED IN}

Nigeria, United States of America, England and Wales. 